\title{
Reconstructing the morphologies and hydrodynamics of ancient rivers from source to sink: Cretaceous Western Interior Basin, Utah, USA
}

\author{
SINÉAD J. LYSTER* (D), ALEXANDER C. WHITTAKER*, GARY J. HAMPSON*, \\ ELIZABETH A. HAJEK $\dagger$, PETER A. ALLISON* and BAILEY A. LATHROP* \\ ${ }^{*}$ Department of Earth Science and Engineering, Imperial College London, London, UK \\ (E-mail: s.lyster17@imperial.ac.uk) \\ $\dagger$ Department of Geosciences, The Pennsylvania State University, Pennsylvania, USA
}

Associate Editor - Jeff Peakall

\begin{abstract}
Quantitative reconstruction of palaeohydrology from fluvial stratigraphy provides sophisticated insights into the response, and relative impact, of tectonic and climatic drivers on ancient fluvial landscapes. Here, field measurements and a suite of quantitative approaches are used to develop a four-dimensional (space and time) reconstruction of palaeohydrology in Late Cretaceous palaeorivers of central Utah, USA - these rivers drained the Sevier mountains to the Western Interior Seaway. Field data include grainsize and cross-set measurements and span five parallel fluvial systems, two of which include up-dip to down-dip transects, across seven stratigraphic intervals through the Blackhawk Formation, Castlegate Sandstone and Price River Formation. Reconstructed palaeohydrological parameters include fluvial morphologies (flow depths, palaeoslopes, palaeorelief and planform morphologies) and various hydrodynamic properties (flow velocities, water discharges and sediment transport modes). Results suggest that fluvial morphologies were similar in space and time; median flow depths spanned 2 to $4 \mathrm{~m}$ with marginally greater flow depths in southerly systems. Meanwhile palaeoslopes spanned $10^{-3}$ to $10^{-4}$, decreasing downstream by an order of magnitude. The most prominent spatio-temporal change is an up to four-fold increase in palaeoslope at the Blackhawk-Castlegate transition; associated alluvial palaeorelief is tens of metres during Blackhawk deposition and $>100 \mathrm{~m}$ during Castlegate Sandstone deposition. This study observed no change in unit water discharges at the Blackhawk-Castlegate transition, which argues against a climatically driven increase in palaeoslope and channel steepness. These findings instead point to a tectonically driven palaeoslope increase, although one limitation in this study is uncertainty in palaeochannel widths, which directly influences total water discharges. These reconstructions complement and expand on extensive previous work in this region, which enables the efficacy of quantitative reconstruction tools to be tested. Comparison of results with facies-based interpretations indicates that quantitative tools work well, but inconsistencies in more complex reconstructions (for example, planform morphologies) highlight the need for further work.
\end{abstract}

Keywords Fluvial hydrodynamics, fluvial morphologies, Late Cretaceous, North America, palaeohydrology, palaeorivers. 


\section{INTRODUCTION}

The stratigraphic record is a fundamental archive of Earth surface processes in space and time (Wobus et al., 2006; Allen, 2008a,b; Armitage et al., 2011; Whittaker, 2012). A key research challenge is to decode this archive to reconstruct the movement of water and sediment across Earth's surface in the geological past (Castelltort \& Van Den Driessche, 2003; Jerolmack \& Paola, 2010; Ganti et al., 2014; Romans et al., 2016; Straub et al., 2020) effective quantification of palaeohydrology from fluvial stratigraphy is crucial to achieve this goal. Constraints on the morphologies and hydrodynamics of palaeorivers can be used to: resolve the size and scale of ancient catchments (Bhattacharya \& Tye, 2004; Bhattacharya et al., 2016; Eide et al., 2018; Lyster et al., 2020); quantify sediment transport capacities and the magnitudes of sediment exported to oceans (Allen et al., 2013; Holbrook \& Wanas, 2014; Lin \& Bhattacharya, 2017; Sharma et al., 2017); decipher fluvial response to perturbation (Foreman et al., 2012; Foreman, 2014; Colombera et al., 2017; Chen et al., 2018); and reconstruct local palaeogeographies (Li et al., 2018). Importantly, these constraints can be used to investigate hydrological response to longperiod forcing $\left(>10^{6} \mathrm{yr}\right)$ because river behaviour is intrinsically linked to tectono-climatic boundary conditions over geological timescales (Duller et al., 2010; Whitchurch et al., 2011; Whittaker et al., 2011; Castelltort et al., 2012; Hampson et al., 2013).

However, palaeohydrology is limited by incomplete (or absent) records of palaeorivers (Sadler, 1981; Jerolmack \& Sadler, 2007), uncertainty as to what information fluvial stratigraphy actually preserves (Castelltort \& Van Den Driessche, 2003; Jerolmack \& Paola, 2010; Romans et al., 2016; Straub et al., 2020), and uncertainties associated with data type, data measurement and reconstruction tools (e.g. Bridge \& Tye, 2000). Where it is possible to overcome these challenges, the ability to decipher palaeohydrological information with high fidelity can enable sophisticated insights to be drawn about the sensitivity and response of ancient fluvial systems to tectonic and climatic drivers.

Here, a quantitative framework is used to reconstruct the palaeohydrological evolution of well-known source-to-sink systems of Late Cretaceous central Utah, USA. The focus of this study is the Blackhawk Formation-Castlegate
Sandstone-Price River Formation fluvial succession as outcrops are extensive and welldocumented (Kauffman, 1977; Kauffman \& Caldwell, 1993; Cobban et al., 2006). These strata represent eastward flowing palaeorivers that drained the Sevier orogenic fold-and-thrust belt to the Western Interior Seaway (WIS). Previous work has primarily focused on qualitative inferences of palaeohydrology in these systems (Miall, 1994; Miall \& Arush, 2001; Adams \& Bhattacharya, 2005; McLaurin \& Steel, 2007; Hampson et al., 2012; Flood \& Hampson, 2014), which are sometimes complimented by simple quantitative reconstructions (e.g. Hampson et al., 2013). Meanwhile, quantitative work has mostly focused on architectural-scale elements in these systems, including preservation of channelized bodies and bars and associated autogenic processes, such as avulsion and backwater dynamics (Hajek et al., 2010; Hajek \& Wolinsky, 2012; Flood \& Hampson, 2015; Trower et al., 2018; Chamberlin \& Hajek, 2019; Ganti et al., 2019a). The palaeohydrological evolution of these rivers at the system scale has not been comprehensively addressed using quantitative tools - this study addresses this outstanding research challenge to shed new light on these ancient systems.

Palaeohydrological field data were collected for five parallel transverse fluvial systems (spaced ca 20 to $25 \mathrm{~km}$ apart) across seven stratigraphic intervals within the Campanian stage $(83.6 \pm 0.2$ to $72.1 \pm 0.2 \mathrm{Ma})$ of the Late Cretaceous, which spanned 11.5 Myr (Figs 1 and 2 ). These data allow for high resolution spatiotemporal reconstructions of these systems, both up-dip to down-dip and along depositional strike (Fig. 1). Reconstructed palaeohydrological parameters include: flow depths; palaeoslopes and palaeorelief (specific to the alluvial domain); hydrodynamic properties, including flow velocities, water discharges and sediment transport modes; and planform morphologies. First and foremost, results show how the morphologies and hydrodynamic properties of these palaeorivers varied in space and time. Moreover, reconstruction of palaeoslopes and palaeorelief in the alluvial domain enable evaluation of the competing roles of tectonic and climatic drivers on the evolution of these ancient rivers. Finally, the results provide new insights regarding the extent to which quantitative palaeohydrological methods (which are increasingly borrowed from the field of engineering) can be reconciled with sedimentological observables. 


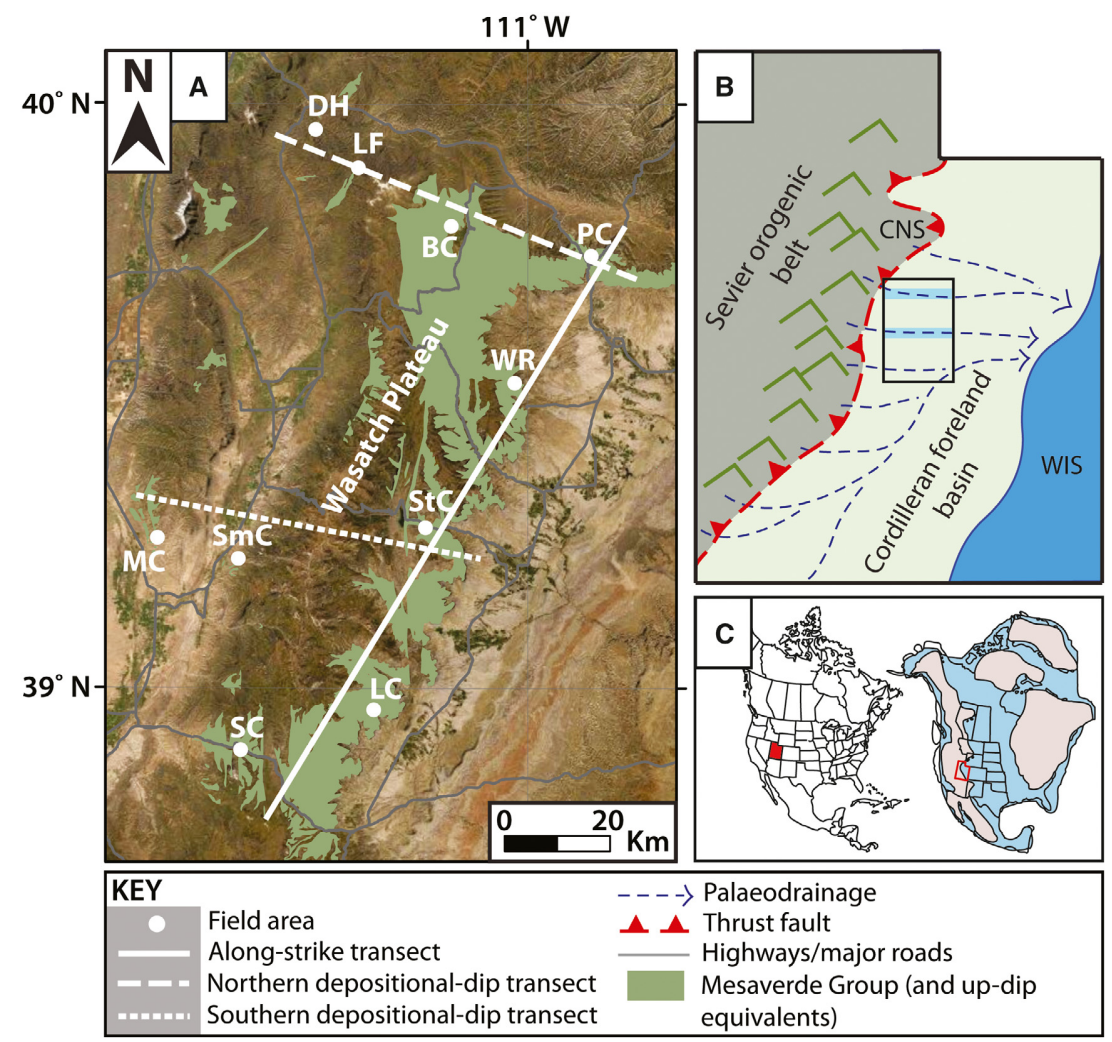

Fig. 1. Study area. (A) Field areas in central Utah, USA, which include Bear Canyon (BC), Dry Hollow (DH), Lake Fork (LF), Link Canyon (LC), Mellor Canyon (MC), Price Canyon (PC), Salina Canyon (SC), Sixmile Canyon $(\mathrm{SmC})$, Straight Canyon (StC) and Wattis Road (WR). The solid white line indicates the along-depositional-strike transect defined in this study, the dashed white line indicates the northern depositional-dip transect defined in this study, and the dotted white line indicates the southern depositional-dip transect defined in this study. (B) A conceptual diagram of Utah palaeogeography and palaeodrainage in the Campanian (Late Cretaceous). Likely configurations of drainage towards the Western Interior Seaway (WIS) are indicated by dashed blue lines. CNS = Charleston-Nebo Salient. The black outlined box indicates the study area (i.e. part A), and the two highlighted drainage routes (shaded blue) represent the northern and southern depositional-dip transects defined in this study (see part A). (C) The location of Utah relative to the modern North American continent (left) and the Late Cretaceous North American continent (right), which features the Western Interior Seaway (blue). Utah is highlighted as a red box.

\section{RESEARCH BACKGROUND}

\section{Palaeohydrology}

Palaeohydrological interpretations traditionally derive from analysis of facies associations in fluvial strata, particularly of architectural-scale elements (Miall, 1994; Miall \& Arush, 2001; Adams \& Bhattacharya, 2005; McLaurin \& Steel, 2007; Hampson et al., 2012; Hampson et al., 2013; Flood \& Hampson, 2014), and increasingly take advantage of high-resolution remote imagery and three-dimensional outcrop models (Hajek \& Heller, 2012; Rittersbacher et al., 2014; Chamberlin \& Hajek, 2019). However, a combination of empirical, theoretical and experimental work has led to the development of fluid and sediment transport models that are applicable to geological questions (e.g. van Rijn, 1984b; Ferguson \& Church, 2004; Parker, 2004; Wright \& Parker, 2004; Mahon \& McElroy, 2018), enabling more sophisticated inferences of palaeohydrology from the rock record.

Recent quantitative research has focused on maximizing the ability to accurately reconstruct the evolution of fluvial landscapes in the geological past. Some efforts have centred on connecting landscape surface kinematics to stratal preservation (Paola \& Borgman, 1991; Castelltort \& Van Den Driessche, 2003; Jerolmack \& Mohrig, 2005; 


\begin{tabular}{|c|c|c|c|c|}
\hline \multirow{2}{*}{\multicolumn{2}{|c|}{ Stage }} & \multicolumn{2}{|c|}{ Stratigraphic unit } & \multirow{3}{*}{$\frac{\text { Interval }}{7}$} \\
\hline & & W. Wasatch & E. Wasatch & \\
\hline \multirow{8}{*}{ 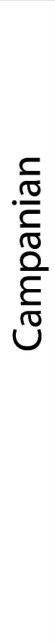 } & \multirow{3}{*}{$\begin{array}{l}\frac{1}{2} \\
\frac{0}{2}\end{array}$} & \multirow{4}{*}{$\begin{array}{c}\text { Price River } \\
\text { Conglomerate }\end{array}$} & $\begin{array}{l}\text { Price River } \\
\text { Formation }\end{array}$ & \\
\hline & & & $\begin{array}{l}\text { Upper Castlegate } \\
\text { Sandstone }\end{array}$ & 6 \\
\hline & & & $\begin{array}{c}\text { Middle } \\
\text { Castlegate } \\
\text { Sandstone }\end{array}$ & 5 \\
\hline & \multirow[t]{2}{*}{$\frac{\frac{0}{\overline{0}}}{\frac{0}{\Sigma}}$} & & $\begin{array}{c}\text { Lower } \\
\text { Castlegate } \\
\text { Sandstone }\end{array}$ & 4 \\
\hline & & \multirow{4}{*}{$\begin{array}{l}\text { Indianola } \\
\text { Group }\end{array}$} & \multirow{3}{*}{$\begin{array}{l}\text { Blackhawk } \\
\text { Formation }\end{array}$} & 3 \\
\hline & \multirow{3}{*}{ ऐò } & & & 2 \\
\hline & & & & 1 \\
\hline & & & $\begin{array}{l}\text { Star Point } \\
\text { Sandstone }\end{array}$ & \\
\hline
\end{tabular}

Fig. 2. Regional stratigraphy and up-dip (western Wasatch Plateau) to down-dip (eastern Wasatch Plateau) stratigraphic correlation followed in this study. Shaded intervals indicate the stratigraphic intervals used in this study (note that they are not of equal duration). 1 = lower Blackhawk Formation; $2=$ middle Blackhawk Formation; 3 = upper Blackhawk Formation; 4 =lower Castlegate Sandstone; $5=$ middle Castlegate Sandstone; $6=$ upper Castlegate Sandstone (Bluecastle Tongue); 7 = (lowermost) Price River Formation. Dashed lines indicate an approximate interval boundary. Modified and compiled using data from Fouch et al. (1983), Robinson \& Slingerland (1998), Miall \& Arush (2001), Horton et al. (2004), Cobban et al. (2006), Aschoff \& Steel (2011a, 2011b), Bartschi et al. (2018). Price River Conglomerate nomenclature follows Aschoff \& Steel (2011a,b).

Jerolmack \& Paola, 2010; Hajek \& Wolinsky, 2012; Ganti et al., 2013; Ganti et al., 2014; Reesink et al., 2015; Romans et al., 2016; Ganti et al., 2020; Leary \& Ganti, 2020; Straub et al., 2020) and a number of these studies have focused on Late Cretaceous fluvial strata in central Utah (Flood \& Hampson, 2015; Trower et al., 2018; Chamberlin \& Hajek, 2019; Ganti et al., 2019a). Meanwhile, other quantitative work has applied fluid and sediment transport models to stratigraphic field data, with an overarching goal of constraining the characteristics of catchments, regional systems or entire fluvial landscapes in the geological past (Ganti et al., 2019b; Lapôtre et al., 2019), or even on other planetary bodies (Lamb et al., 2012; Buhler et al., 2014; Hayden et al., 2019; Lapôtre et al., 2019). This includes using quantitative palaeohydrological tools to reconstruct water and sediment discharges within mass balance frameworks (Holbrook \& Wanas, 2014; Lin \& Bhattacharya, 2017; Sharma et al., 2017), decipher local palaeogeographies (Bhattacharyya et al., 2015; Li et al., 2018), characterize pre-vegetation rivers (Ganti et al., 2019b), and reconstruct fluvial response to climatic perturbations for well-preserved fluvial strata straddling events such as the Palaeocene-Eocene Thermal Maximum (PETM) (Foreman et al., 2012; Foreman, 2014; Colombera et al., 2017; Chen et al., 2018; Duller et al., 2019).

Despite the breadth of quantitative palaeohydrological tools available, previous applications to fluvial stratigraphic field data have typically centred on individual catchments and instantaneous or short-period intervals (i.e. individual discharge events and mean annual discharges) (Holbrook \& Wanas, 2014; Lin \& Bhattacharya, 2017; Sharma et al., 2017), or reconstructions across stratigraphic boundaries and short-period tectono-climatic events, such as the PETM (Foreman et al., 2012; Foreman, 2014; Colombera et al., 2017; Chen et al., 2018; Duller et al., 2019). Far fewer studies have focused on long-period intervals, such as the evolution of source-to-sink systems across geological timescales $\left(>10^{6} \mathrm{yr}\right)$. This outstanding opportunity can be exploited in Late Cretaceous fluvial systems of central Utah, where outcrop availability supports a fourdimensional (space and time) study in a region subject to active tectonics, spanning both Sevier and Laramide deformation.

\section{Tectono-geographic setting and palaeodrainage}

Input of sediment to the Late Cretaceous WIS was dominated by the western margin, where rivers draining the active Sevier fold-and-thrust belt eroded and transported huge volumes of clastic sediments eastward into the foreland basin (Spieker, 1946; Armstrong, 1968; Kauffman, 1977; Hay et al., 1993; Kauffman \& Caldwell, 1993) (Fig. 1B and C). This led to the deposition and progradation of a large, asymmetrical clastic wedge on the western WIS margin. This study focuses on Campanian non-marine clastic sediments of this wedge in central Utah, USA (Figs 1 to 3), where palaeodrainage is relatively well-constrained (Bartschi et al., 2018; Pettit et al., 2019). Multiple transverse fluvial systems drained the Sevier thrust belt in this area (Fig. 1B). Several studies have additionally interpreted an axial, or 

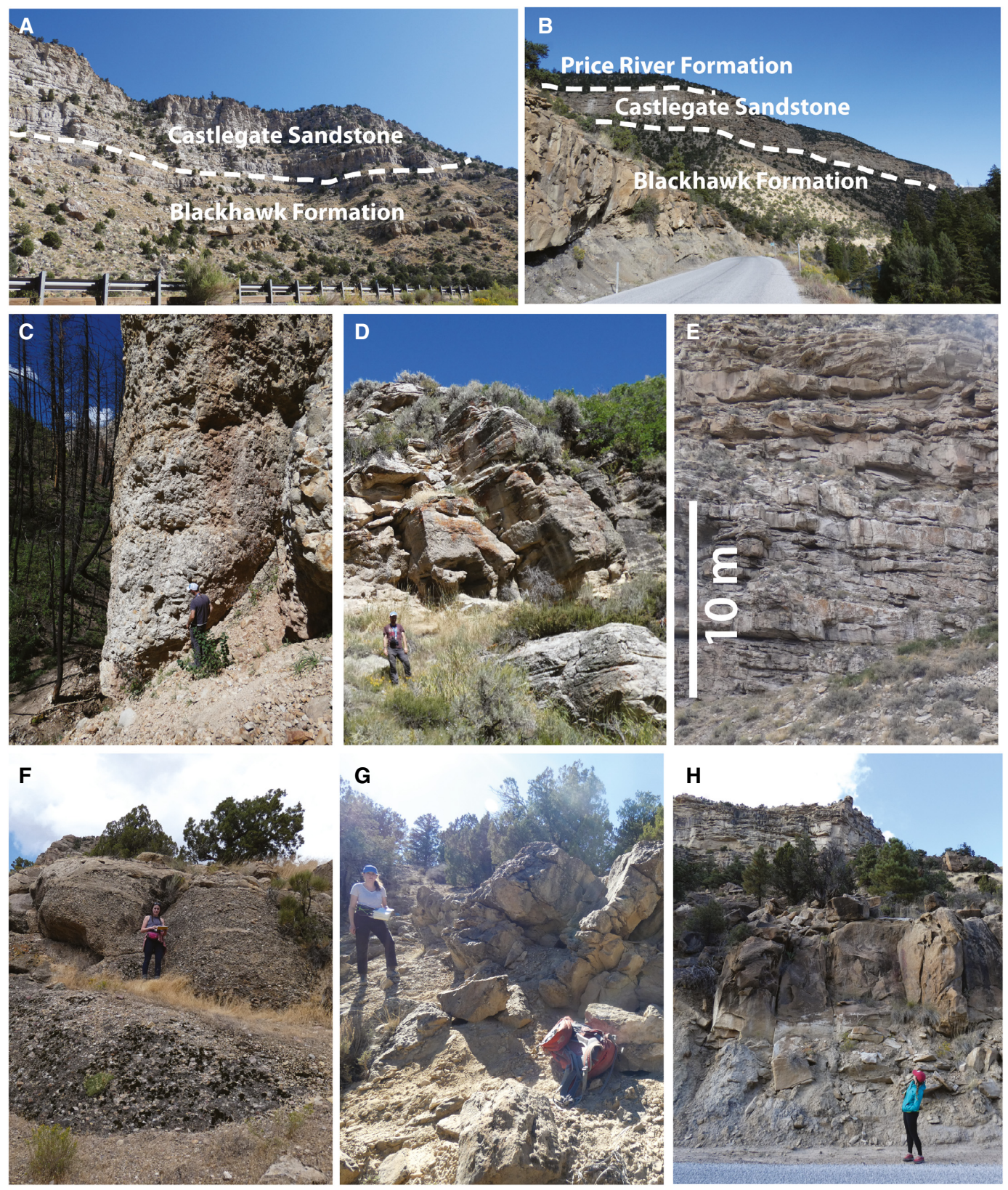

Fig. 3. An overview of fluvial strata from which palaeohydrological field data were collected. Data were collected for five parallel palaeorivers in Late Cretaceous central Utah, USA. These five palaeorivers cropped out in canyons on the eastern front of the Wasatch Plateau - (A) and (B) show typical exposure of the Blackhawk Formation, Castlegate Sandstone and Price River Formation in these canyons. Specifically, (A) shows strata in Salina Canyon, in which the elevation difference between the road and the top of the cliff is $c a 400 \mathrm{~m}$, and (B) shows strata in Straight Canyon, in which the elevation difference between the road and the top of the cliff is ca $450 \mathrm{~m}$ (see Fig. 1), and dashed white lines indicate lithostratigraphic boundaries. For two of these five palaeorivers, data were additionally collected upstream to downstream along defined depositional-dip transects (see Fig. 1). Parts (C) to (E) show deposits on the northern depositional-dip transect. From up-dip to down-dip, (C) shows debris-flow facies of the Price River Conglomerate, (D) shows amalgamated fluvial gravels and sands of the Castlegate Sandstone near Bear Canyon, and (E) shows amalgamated fluvial sands of the Castlegate Sandstone in Price Canyon. Parts (F) to (H) show deposits on the southern depositional-dip transect, for older sediments. From up-dip to down-dip, (F) shows channelized fluvial gravel-sand bodies of the upper Sixmile Canyon Formation in Mellor Canyon, (G) shows a small channelized sandstone body of the upper Sixmile Canyon Formation in Sixmile Canyon, and $(\mathrm{H})$ shows a large channelized sand body of the Blackhawk Formation in Straight Canyon (in the background the Castlegate Sandstone is visible). People for scale are $c a 1.7 \mathrm{~m}$ tall. 
longitudinal, fluvial system that drained north-north-east from the Mogollon Highlands (present day central Arizona) and Cordilleran magmatic arc, which interacted with transverse systems of the Sevier thrust belt (Lawton et al., 2003; Jinnah et al., 2009; Szwarc et al., 2015) (Fig. 1B) and led to down-system sediment mixing (Bartschi et al., 2018; Pettit et al., 2019). Detrital zircon data (Bartschi et al., 2018) indicate that these fluvial systems were dominated by a thrust-belt source in close proximity to the Sevier thrust front, but that more southerly transverse systems may have additionally featured a longitudinal component of drainage (Bartschi et al., 2018; Pettit et al., 2019). Herein, focus is on transverse fluvial systems that predominantly drained the Sevier mountains (Fig. 1).

Tectonic forcing in this region is well-studied (DeCelles, 1994, 2004; DeCelles \& Coogan, 2006) and palaeoclimate has been reconstructed from a variety of palaeontological, geochemical-proxy and modelling studies (e.g. Wolfe \& Upchurch Jr., 1987; Fricke et al., 2010; Miller et al., 2013; Sewall \& Fricke, 2013; Foreman et al., 2015). In central Utah, eastward propagation of the Sevier thrust belt (due to eastward subduction of the Farallon plate) resulted in thin-skinned deformation and movement on the north-south trending Canyon (ca 145 - $110 \mathrm{Ma}$ ), Pahvant (ca 110 $86 \mathrm{Ma})$, Paxton (86 - $75 \mathrm{Ma})$ and Gunnison (75 - 65 Ma) thrust systems (DeCelles, 1994, 2004; DeCelles \& Coogan, 2006). Associated exhumation created substantial topographic relief in the Sevier mountains, which has been described as 'Andean' in scale with mean elevations approaching near $4000 \mathrm{~m}$ (Sewall \& Fricke, 2013; Foreman et al., 2015). Modelling results and stable isotope evidence suggest a strong monsoonal precipitation along the eastern flank of the Sevier mountains and seasonal flooding across low-relief regions (Roberts, 2007; Roberts et al., 2008; Fricke et al., 2010; Sewall \& Fricke, 2013). The tectono-geographic set-up of the Western Interior was particularly conducive to a monsoonal climate - the proximity of a warm sea to high elevation mountains commonly results in strong seasonal precipitation and convective circulation (e.g. Zhisheng et al., 2001). A seasonal temperate to subtropical climate therefore prevailed throughout Campanian deposition (Parker, 1976b; Kauffman \& Caldwell, 1993; Roberts \& Kirschbaum, 1995). The Campanian onset of thick-skinned deformation as the subducting Farallon plate transitioned to lower- angle, or flat-slab, subduction (DeCelles, 2004) began to manifest as basement-cored Laramide uplifts (for example, San Rafael Swell, central Utah, and Uinta Mountains, northern Utah), which partitioned the Sevier foreland basin and disrupted patterns of both regional subsidence and drainage (Bartschi et al., 2018; Pettit et al., 2019).

\section{Stratigraphic framework}

Establishing a consistent stratigraphic framework in space and time is crucial for system scale palaeohydrological reconstructions. Here, focus is on the Upper Cretaceous Mesaverde Group and up-dip equivalents (Figs 1 and 2) in central Utah, USA, specifically fluvial sediments situated less than $c a 100 \mathrm{~km}$ from the Sevier orogenic front (DeCelles \& Coogan, 2006) in the flexurally subsiding foredeep (Fig. 3). These sediments include the Blackhawk Formation, Castlegate Sandstone and Price River Formation along the eastern front of the Wasatch Plateau (Figs 1 to 3). Up-dip, on the western Wasatch Plateau, the Blackhawk-Castlegate-Price River succession is correlated with the Sixmile Canyon Formation (Indianola Group) and the Price River Conglomerate [following Robinson \& Slingerland (1998); Horton et al. (2004); Aschoff \& Steel (2011a,b)] (Figs 1 to 3). Up-dip to downdip, these sediments encompass the entire alluvial domain of these palaeorivers draining the Sevier highlands. A broad summary of field sites and the stratigraphic framework (Figs 1 and 2) is given below - extended information regarding regional stratigraphy and correlations is provided in the Supporting Information.

Down-dip field sites were grouped spatially into five field areas that represent five parallel transverse fluvial systems draining the Sevier thrust front: Price Canyon, Wattis Road, Straight Canyon (including Joe's Valley Reservoir), Link Canyon and Salina Canyon (Figs 1 and 3). These five field areas are approximately $c a 50 \mathrm{~km}$ from up-dip alluvial fan lobes (Figs 1 and 3). Assuming typical outlet spacings of rivers draining orogenic fronts (ca $25 \mathrm{~km}$ ) (Hovius, 1996), it is likely that these field areas represent five distinct palaeorivers and form a $c a 125 \mathrm{~km}$ transect along depositional strike. For the two up-dip to down-dip transects (Fig. 1), the northern transect included four field areas: Dry Hollow, Lake Fork, Bear Canyon, and terminating at Price Canyon (Fig. 3C to E), and the southern transect included three field areas: Mellor Canyon, 
Sixmile Canyon, and terminating at Straight Canyon (Fig. 3D to F). These transects follow those widely implemented in previous work, both along-strike (Hampson et al., 2012; Hampson et al., 2013; Flood \& Hampson, 2014, 2015; Chamberlin \& Hajek, 2019) and up-dip to downdip (Robinson \& Slingerland, 1998; Horton et al., 2004; Aschoff \& Steel, 2011a,b).

In addition to grouping field sites in space, they were also grouped in time. In this study seven stratigraphic intervals were defined: $1=$ lower Blackhawk Formation; $2=$ middle Blackhawk Formation; 3 = upper Blackhawk Formation; $4=$ lower Castlegate Sandstone; $5=$ middle Castlegate Sandstone; $6=$ upper Castlegate Sandstone (Bluecastle Tongue); and $7=$ (lowermost) Price River Formation (Fig. 2).

Down-dip, on the eastern front of the Wasatch Plateau, it is straightforward to assign sediments of the Blackhawk-Castlegate-Price River succession to the appropriate 'space-time' interval by facies associations, following extensive work that has been undertaken in this region (Lawton, 1983, 1986b; Miall, 1994; van Wagoner, 1995; Yoshida et al., 1996; Miall \& Arush, 2001; Lawton et al., 2003; Adams \& Bhattacharya, 2005; Hampson et al., 2012; Hampson et al., 2013; Flood \& Hampson, 2014; Hampson et al., 2014; Flood \& Hampson, 2015). The lower-middle Campanian Blackhawk Formation represents deposition on coastal plains behind wavedominated deltaic shorelines which, up-section, pass landward into alluvial and fluvial plains (Hampson, 2010; Hampson et al., 2012; Hampson et al., 2013). The size and abundance of channelized fluvial sand bodies (deposited by both single-thread and multi-thread rivers) increase from base to top of the Blackhawk Formation (Adams \& Bhattacharya, 2005; Hampson et al., 2012; Hampson et al., 2013; Flood \& Hampson, 2015). The middle-upper Campanian Castlegate Sandstone is situated atop the Blackhawk Formation and is an extensive, cliffforming river-dominated deposit. The lower Castlegate Sandstone and upper Castlegate Sandstone (Bluecastle Tongue) comprise amalgamated braided fluvial channel-belt deposits, whereas the middle Castlegate Sandstone comprises less amalgamated, more meandering, fluvial channel-belt deposits with interbedded mudstones (Fouch et al., 1983; Lawton, 1986b; Miall, 1994; van Wagoner, 1995; Yoshida et al., 1996; Miall \& Arush, 2001). The ledge-forming upper Campanian Price River Formation sits conformably atop the Castlegate Sandstone and comprises large channelized sand bodies with interbedded siltstones and mudstones - channelized sand bodies form $c a 75 \%$ of the formation (Lawton, 1983, 1986b). Fluvial sediments of the Price River Formation represent the end of Sevier thrusting; the late Maastrichtian-Eocene North Horn Formation unconformably overlies the Price River Formation.

Up-dip, on the western Wasatch Plateau, correlative strata include more proximal sediments of the Indianola Group and Price River Formation, which is now known to not be timeequivalent with the down-dip Price River Formation exposed near Price, Utah (Robinson \& Slingerland, 1998; Horton et al., 2004; Aschoff \& Steel, 2011a,b). To avoid confusion, these updip strata are here referred to as the Price River Conglomerate, following Aschoff \& Steel (2011a, b). Up-dip to down-dip correlations are limited by incomplete exposure on the western Wasatch Plateau and difficulty in dating conglomerates (see Supporting Information). Nevertheless, Robinson \& Slingerland (1998) used palynology to correlate these strata across a variety of localities on the Wasatch Plateau (Fig. 2), which can be traced in seismic reflection data (Horton et al., 2004). The up-dip Price River Conglomerate is time-correlative with the down-dip lower, middle and upper Castlegate Sandstone, and Price River Formation (Robinson \& Slingerland, 1998; Horton et al., 2004; Aschoff \& Steel, 2011a,b), and is characterized by quartzitedominated synorogenic fanglomerates and few gravel-sand fluvial bodies (Robinson \& Slingerland, 1998; Aschoff \& Steel, 2011a,b). Of the Indianola Group, the upper Sixmile Canyon Formation is time-correlative with the Blackhawk Formation (Lawton, 1982; Fouch et al., 1983; Lawton, 1986b) and is predominantly characterized by synorogenic gravel-sand fluvial facies, spanning polymictic fluvial conglomerates to medium-coarse-grained sandstones (Lawton, 1982, 1986a,b). Here a conservative approach is taken to up-dip to down-dip correlations; the upper Sixmile Canyon Formation of the Indianola Group (intervals 1 to 3 ) is time-averaged, and the Price River Conglomerate (intervals 4 to 7) is also time-averaged, but exceptions were made where field sites were known to be situated at either the top of the upper Sixmile Canyon Formation or at the top/base of the Price River Conglomerate. A full description of these correlations, including new logging in Mellor Canyon, is presented in the Supporting Information. 
Each depositional-dip transect is pinned at the most downstream location, i.e. it is assumed that the most down-dip sites in each transect (Price Canyon and Straight Canyon) are approximately parallel and at the same downstream distance. Transects then work upstream, such that the most up-dip field site (Dry Hollow; northern transect) is at a downstream distance of $0 \mathrm{~km}$. Downstream distances follow Robinson \& Slingerland (1998) - post-depositional extension is not corrected for. Alternatively, when reconstructing along-depositional-strike transects, transects are pinned at the most northern location (Price Canyon) with an along-strike distance of $0 \mathrm{~km}$, meanwhile southern locations have along-depositional-strike distances up to $125 \mathrm{~km}$.

\section{METHODS}

Data were collected from channel-fill stratigraphy (cross-stratified sandstone and gravel deposits are interpreted as channel floor deposits) and were time-averaged across each stratigraphic space-time interval (field sites are listed in Table S2 in Supplementary S4). These field data, including uncertainties, were propagated through a quantitative framework to reconstruct the morphologies and hydrodynamics (flow depths, palaeoslopes, river long profiles, flow velocities and discharges, sediment transport modes and likely planform morphologies) of palaeorivers in both space and time.

\section{Field observations}

\section{Grain size}

At each field site the coarse-fraction $(>2 \mathrm{~mm}$ in diameter $)$ and sand-fraction $(<2 \mathrm{~mm}$ in diameter) grain sizes of channel-fill deposits were established (Fig. 4A and B). For coarse-fractions, grain-size distributions were measured via Wolman point counts (Wolman, 1954) (Fig. 4A); this technique has been successfully used to decode spatio-temporal trends in grain size (e.g. Whittaker et al., 2011; D'Arcy et al., 2017; Brooke et al., 2018). For sand-fractions, scaled photographs were processed in ImageJ software and, similarly, the long axis of a minimum of 50 randomly selected grains was measured to recover grain-size distributions (Fig. 4B). From each measured grain-size distribution, the median grain size, $D_{50}$, and $84^{\text {th }}$ percentile, $D_{84}$, were extracted. Where grain-size facies were disparate, for example gravel topped with sand, data were collected for each grain-size facies and the proportions of each were estimated (Fig. 4C).

In order to achieve representative sampling for spatio-temporal grain-size trends, multiple grainsize observations were collected at each field site. Not only were data collected for each grain-size facies (Fig. 4A to C), but depending on overall outcrop extent Wolman point counts were repeated and/or additional scaled photographs were taken for ImageJ processing at intermittent stratigraphic intervals (for example, one count per 5 to $10 \mathrm{~m}$ of strata or per channelized body). The extent of each field site can be approximated as the extent of outcrop apparent in Fig. $3 \mathrm{C}$ to $\mathrm{H}$. From these data an average grain size was produced for both the sand-fraction and gravelfraction at each field site. Because each spacetime interval includes multiple field sites, this results in multiple average sand-fraction and gravel-fraction grain sizes, capturing channel-fill deposits from several channelized bodies. Finally, a bulk-grain-size was produced for each space-time interval using the gravel to sand proportions at each field site - each site within a space-time interval was assigned equal weighting. Further information regarding grain-size data collection, including axis selection, sample size sufficiency and weighting, is presented in the Supporting Information.

\section{Cross-sets}

Cross-set heights were measured as these data can be used to reconstruct original bedform heights and formative flow depths. Trough cross-bedding and planar cross-bedding, which are inherently indicative of bedload transport, were present at nearly all field sites. They occurred predominantly in sand-grade deposits, but also in granule to pebble-grade deposits (Fig. 4D to F). To establish mean cross-set heights, the sampling strategy of Ganti et al. (2019b) was followed. Cross-set boundaries (i.e. the lower, asymptotic bounding surface and the upper, erosional bounding surface) were delineated and then heights were measured at regular intervals along the entire width of the cross-set dip-section (Fig. 4G to I). Measurements were made to a precision of $\pm 5 \mathrm{~mm}$. This protocol was repeated for individual cross-sets within cosets to establish a mean cross-set height for each individual cross-set. Subsequently, maximum cross-set heights (i.e. the maximum distance between lower and upper bounding surfaces) 

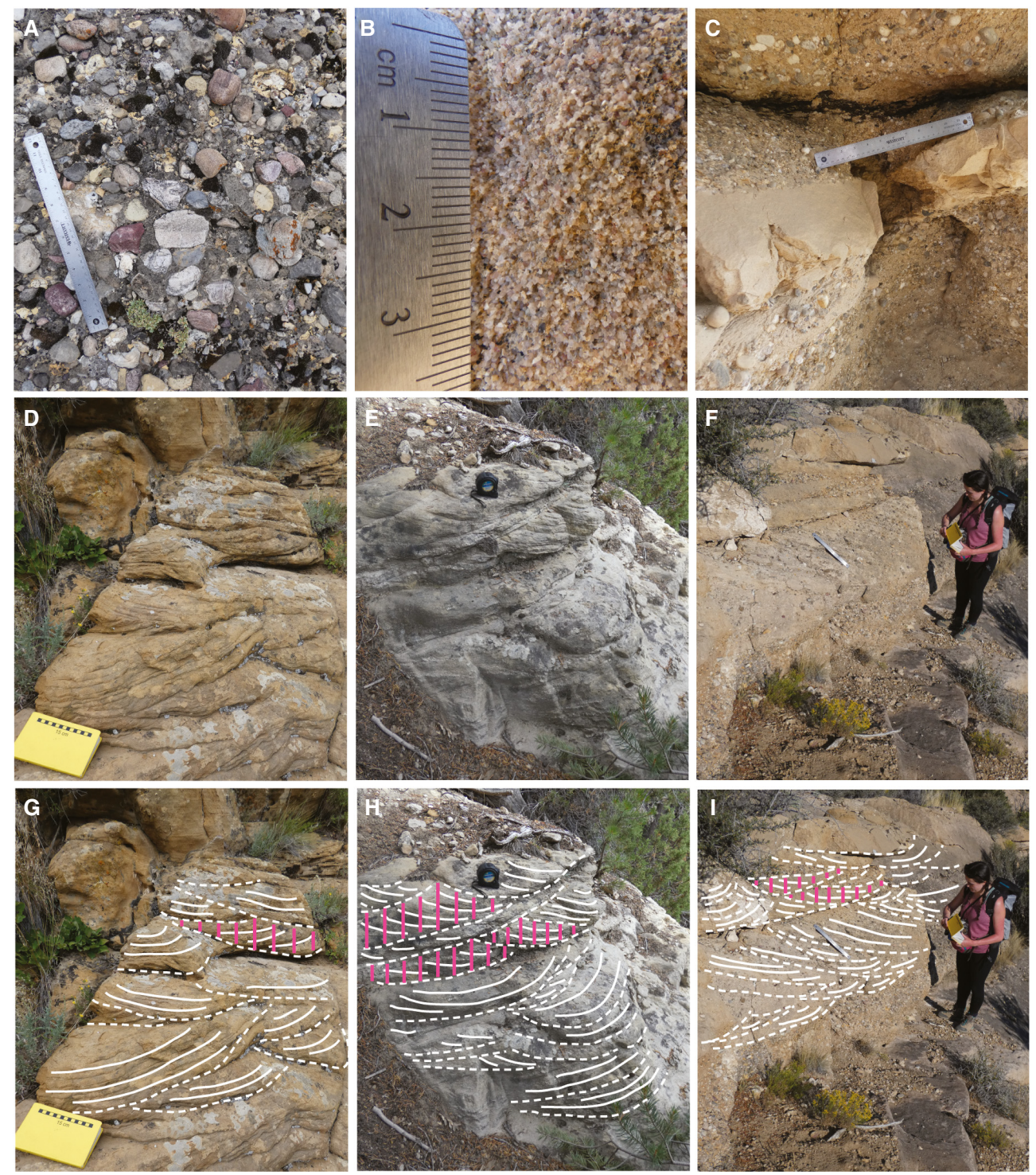

Fig. 4. Field data collection included grain-size measurements for (A) gravel and (B) sand fractions, as well as (C) estimates of the proportions of different grain-size facies. Parts (D) to (F) depict cross-bedding, and parts (G) to (I) depict interpreted versions of the same images. Dashed white lines indicate bounding surfaces of individual cross-sets and solid white lines indicate selected foresets within individual cross-sets. To exemplify sampling procedure when determining mean cross-set height, solid pink lines demonstrate how heights are measured for selected cross-set dip sections. Field notebook with $15 \mathrm{~cm}$ scale, tape measure and $30 \mathrm{~cm}$ rule for scale.

were measured for a representative sample across the exposed outcrop (usually $n=25-50$ ).

From cross-sets for which height distributions were measured $(n=470)$, the mean, $84^{\text {th }}$ percentile $\left(P_{84}\right)$ and maximum heights of each individual cross-set were extracted. From these data, the relationship between maximum and mean cross-set heights was established. This new relationship was then used to estimate mean cross- set heights from all measured maximum crossset heights $(n=4053)$. This maximised the amount of field data that could be collected, and therefore analysed, at each field site - it is more efficient to measure maximum cross-set heights than height distributions of individual crosssets. These estimates of mean cross-set heights were propagated through subsequent calculations, as measurements of mean cross-set heights 
are more appropriate than maximum cross-set heights in reconstruction of palaeohydrological parameters (for example, Eq. 1).

\section{Channel geometry and architectural element data}

Above grain and bedform-scales, channel geometries and major architectural elements were also measured, where possible, using a Haglöf Laser Geo laser range finder (Haglöf Sweden AB, Langsle, Sweden) to a precision of $\pm 5 \mathrm{~cm}$. This included maximum channel body/storey thicknesses and bar-scale clinoform heights. Previous work in this region has documented the dimensions and distributions of fluvial architectural elements using high-resolution imagery and 3D outcrop models (Hajek \& Heller, 2012; Rittersbacher et al., 2014; Flood \& Hampson, 2015; Chamberlin \& Hajek, 2019). Field data collection therefore focused on grain-size and cross-set measurements, with compilation of published secondary data (alongside new data from this study) to augment field data and evaluate the palaeohydrological reconstructions herein (see Tables S4 and S5 in Supplementary S6).

\section{Quantitative palaeohydrology}

\section{Channel geometries}

To calculate original bedform heights from cross-set measurements, the relation of Leclair \& Bridge (2001) was used, which is based on theoretical work by Paola \& Borgman (1991). Leclair \& Bridge (2001) showed that mean bedform (i.e. dune) height, $h_{d}$, can be approximated as a function of mean cross-set height, $h_{x s}$, as:

$$
h_{d}=2.9( \pm 0.7) h_{x s}
$$

where 2.9 is the mean and 0.7 is the standard deviation. Given that exact error margins of palaeohydrological inversion methods cannot be known, a Monte Carlo uncertainty propagation method is used in this study to estimate uncertainty and offer plausible spreads of values for each reconstructed palaeohydrological parameter. In Eq. 1, uncertainty is represented as the mean $(\mu)$ and one standard deviation $(\sigma)$. As such, $10^{6}$ random samples were generated between bounds defined by $\mu-\sigma$ and $\mu+\sigma$. Samples were generated from a uniform distribution as the shape and the scale of the full distribution of the data is not known - this approach avoids introduction of additional assumptions. These values are then propagated through subsequent calculations.

While bedform height generally scales with flow depth, the mechanistic explanation for this is not fully resolved. As such, many scaling relations simply relate bedform height and flow depth (e.g. Yalin, 1964), whereas some incorporate additional parameters such as Froude number, $D_{50}$, and transport stage (e.g. Gill, 1971; van Rijn, 1984a); however their incorporation does not improve predictive power. Bradley \& Venditti (2017) revisited previous bedform height-flow-depth scaling relations and derived a new relation between $h_{d}$ and median formative flow depth, $H$, based on $>380$ field observations, where:

$$
H=6.7 h_{d}
$$

In detail, Bradley \& Venditti (2017) derived two relations to reconstruct $H$ from $h_{d}$. Their first relation was derived from regression analysis and recovered $\mu$ and $\sigma$, however the authors argued that this relation is not useful as the data are not normally or log-normally distributed, and that the tails of the distribution are not fully represented (Bradley \& Venditti, 2017). The authors additionally presented a non-parametric relation to derive median $H$ (Eq. 2) with a probabilistic uncertainty estimator in which the first and third quartiles of $H$ are given by $H=4.4 h_{d}$ and $H=10.1 h_{d}$, respectively (Bradley \& Venditti, 2017). Bradley \& Venditti (2017) noted that this probabilistic uncertainty estimator better represented their data, because it does not assume an underlying distribution. This relation is more appropriate in palaeohydrological reconstructions as, with a larger uncertainty estimate, it offers a broader spread of possible $H$ values. As such, $10^{6}$ uniformly distributed random samples were generated between 4.4 and 10.1, and these model parameter values were used to generate likely palaeoflow depths in these ancient systems. Where cross-bedding was absent (i.e. the most up-dip field sites), channel-body thicknesses were used as a proxy for flow depth.

Similar to $H$, channel width, $W$, can be estimated using scaling relations as direct measurement is not normally possible from outcrop. Bridge \& Mackey (1993) proposed the relation $W=8.8 H^{1.82}$ for single-thread channels. Alternatively, widths of fully-braided channel systems can be approximated as, for example, $W=$ $42 H^{1.11}$ (Leopold \& Maddock Jr, 1953). However, estimates of $W$ from outcrop data and scaling 
relations are particularly tentative and, where systems are braided, subject to further uncertainty pertaining to the number of threads. As such, results in this study are reported per unit width.

\section{Palaeoslopes and palaeorelief}

Palaeoslopes were estimated using two independent methodologies, adapted from Ganti et al. (2019a). First, Shields stress, $\tau^{*}$, was estimated using the bedform stability diagram of Carling (1999), which expresses bedform stability in terms of $\tau^{*}$ and $D_{50}$ (for $D_{50}<33 \mathrm{~mm}$ ). Minimum and maximum bounds of $\tau^{*}$ for the stable existence of dunes were then identified for a range of $D_{50}$ values. Then, $10^{6}$ uniformly distributed random samples of $\tau^{*}$ were generated between these grain-size-dependent bounds. Where $D_{50}$ exceeded $33 \mathrm{~mm}$, and in the absence of bedforms, possible $\tau^{*}$ values of 0.03 to 0.06 were assigned. To reconstruct palaeoslope, $S$, the bed shear stress, $\tau_{b}$, was approximated as the depth-slope product $\left(\tau_{b}=\rho g H S\right)$ and then $S$ can be given as:

$$
S=\frac{R D_{50} \tau^{*}}{H}
$$

where $R$ is the dimensionless submerged specific gravity of sediment in water (1.65 for quartz) and $H$ is the flow depth ( $\rho$ is density and $g$ is acceleration due to gravity). For the second approach, the method of Trampush et al. (2014) was used, which is based on Bayesian regression analysis of bankfull measurements in modern alluvial rivers $(n=541)$; here slope is expressed as:

$$
\log S=\alpha_{0}+\alpha_{1} \log D_{50}+a_{2} \log H
$$

where the constants are given by $\alpha_{0}=-2.08 \pm 0.036, \quad \alpha_{1}=0.254 \pm 0.016, \quad$ and $\alpha_{2}=-1.09 \pm 0.044$. Again, $10^{6}$ values of $\alpha_{0}, \alpha_{1}$ and $\alpha_{2}$ were generated (uniformly distributed random samples between $\mu-\sigma$ and $\mu+\sigma$ ). Having propagated $10^{6}$ values of $\tau^{*}, H, \alpha_{0}, \alpha_{1}$ and $\alpha_{2}$ into these calculations, $10^{6}$ values of $S$ were recovered for both Eqs 3 and 4, which can then be contrasted.

Along up-dip to down-dip transects, palaeoslope estimates can be used to infer the shape of the river long profile, and therefore palaeorelief, in the alluvial domain. Palaeorelief was reconstructed using estimates of $S$ from Eqs 3 and 4. For simplicity, median $S$ was extracted from these values and used to derive palaeorelief. The local slope at downstream position $x, S_{x}$, can be related to its upstream contributing catchment area, $A_{x}$, (Hack, 1973; Flint, 1974; Whipple, 2004) as:

$$
S_{X}=k_{S} A_{X}^{-\theta}
$$

where $k_{\mathrm{s}}$ is the steepness index and $\theta$ is the concavity, typically between 0.4 and 0.7 (Tucker \& Whipple, 2002). Given that the palaeo-concavity is unknown, a range of plausible concavities (0.4, 0.5 and 0.6) were tested to gauge the spread of possible results. Following Hack's law, local catchment length, $L_{X}$, is related to $A_{X}$ by $L_{X}=$ $C_{H} A_{x}{ }^{h}$, where $C_{H}$ is the Hack coefficient, commonly taken as near 2 when $L_{X}$ and $A_{X}$ are in units of $\mathrm{km}^{2}$ (Castelltort et al., 2009), and $h$ is the Hack exponent, commonly taken as 0.5 (Hack, 1957). Using Hack's law, local slope can instead be estimated as a function of downstream distance, where:

$$
S_{X}=k_{s} L_{x}^{-\theta / h}
$$

$k_{s}$ is calculated from field data using downsystem palaeoslope estimates and knowledge of catchment lengths at each downstream location. Because this study solely focuses on the alluvial domain, this means that up-dip fan apexes would have a catchment length of $0 \mathrm{~km}$. Here, the most up-dip field sites are set as having a catchment length of $5 \mathrm{~km}$ to allow for additional up-dip fan length. Knowledge of distance to the coeval palaeoshoreline from the most down-dip sites (Price Canyon and Straight Canyon) is also required. Based on previous studies, approximate distances to the palaeoshoreline are set as ca $10 \mathrm{~km}$ for the lower Blackhawk Formation, ca $35 \mathrm{~km}$ for the middle Blackhawk Formation, $c a 50 \mathrm{~km}$ for the upper Blackhawk Formation, $c a$ $110 \mathrm{~km}$ for the Castlegate Sandstone (Hampson et al., 2012; Hampson et al., 2013) and ca $200 \mathrm{~km}$ for the Price River Formation (Hettinger \& Kirschbaum, 2002; Aschoff \& Steel, 2011a). A nonlinear least squares regression was used to find best fit palaeoslope profiles (Eq. 6) for both the northern and southern transects at each time interval. Palaeoslope profiles were then transformed into river long profiles by summing elevation increments along the downstream length to the palaeoshoreline. This elevation decrease is indicative of the likely relief in the alluvial domain of these palaeorivers.

\section{Hydrodynamics}

In subsequent calculations, values derived from Monte Carlo uncertainty propagation were used, 
i.e. $10^{6}$ estimates of $H, S$, etc. Specifically, estimates of $S$ derived from the Shields stress inversion (Eq. 3) were carried forward. Flow velocities, $U$, were calculated following Manning's Equation, where:

$$
U=\frac{1}{n} H^{\frac{2}{3}} S^{\frac{1}{2}}
$$

and $n$ is Manning's constant, set as 0.03 . Water discharges were then estimated by multiplying flow velocity by flow depth, to obtain discharge per unit width $(Q=U H)$.

To determine dominant mode of sediment transport, the Rouse number, $Z$, was calculated as:

$$
Z=\frac{W_{s}}{\beta \kappa u_{*}}
$$

where $\beta$ is a constant that correlates eddy viscosity to eddy diffusivity, typically taken as $1, \kappa$ is the von Karman constant, taken as 0.4 , and $u *$ is the bed shear velocity $\left(g H S^{0.5}\right)$. Sediment settling velocity, $w_{s}$, was calculated as a function of grain size following Ferguson \& Church (2004):

$$
w_{S}=\frac{R g D_{50}^{2}}{C_{1} V+\left(0.75 C_{2} \operatorname{Rg} D_{50}^{3}\right)^{0.5}}
$$

where $V$ is the kinematic viscosity of water $\left(1 \times 10^{-6} \mathrm{~m}^{2} \mathrm{~s}^{-1}\right.$ for water at $\left.20^{\circ} \mathrm{C}\right)$ and $C_{1}=18$ and $C_{2}=1$ are constants associated with grain sphericity and roundness. With $Z$, dominant mode of sediment transport is typically wash load for $Z<0.8,100 \%$ suspended load for $0.8<Z<1.2,50 \%$ suspended load (i.e. mixed load) for $1.2<Z<2.5$, and bedload for $Z>2.5$. To corroborate inferred sediment transport modes, the particle Reynolds number, $R e_{p}$, was additionally calculated in line with previous work (cf. Parker, 2004) as:

$$
R e_{p}=\frac{\sqrt{R g D_{50}} D_{50}}{V}
$$

and plotted as a function of $\tau^{*}$, following Dade \& Friend (1998). This enables field results to be contrasted with data that are typical of either suspended, mixed or bedload sediments (Leopold \& Wolman, 1957; Schumm, 1968; Chitale, 1970; Church \& Rood, 1983; Andrews, 1984), and to identify where these data are positioned among characteristic flow regimes (no sediment transport; ripples and dunes; upper plane beds) following Allen (1982a,b).
Fluvial style

Fluvial style (i.e. planform morphology) of Blackhawk-Castlegate rivers has been described qualitatively from outcrop architecture (Miall, 1994; Miall \& Arush, 2001; Adams \& Bhattacharya, 2005; Hampson et al., 2013). Here, a quantitative approach is implemented to decipher fluvial style to complement these works, check for consistency, and interpret the interplay between different planform morphologies and the tectonogeographic setting. This is carried out for field areas along the eastern Wasatch Plateau. First, Froude number, Fr, is calculated as:

$$
F r=\frac{U}{\sqrt{g H}}
$$

and, then, depth/width ratios were plotted against palaeoslope/Froude ratios (Parker, 1976a). Various flow widths were assigned to determine what depth/width ratios are required such that the data fall within the theoretical stability fields for single-thread and multi-thread fluvial planform morphologies. These flow widths are then contrasted with estimates of apparent maximum flow width from architectural analysis of channelized sandstone bodies (e.g. Flood \& Hampson, 2015) and field interpretations of fluvial style (Miall, 1994; Miall \& Arush, 2001; Adams \& Bhattacharya, 2005; Hampson et al., 2013).

For all palaeohydrological parameters the median (second quartile) result is presented. Where minima and maxima are presented, these bounds reflect the full spread of recovered values. These are offered as plausible minimum and maximum values for the median, derived from propagation of uncertainty margins. In instances where a first to third interquartile range is additionally presented, specifically in 'box and whisker' plots, this is the first to third interquartile range that has been extracted for each parameter from the $10^{6}$ values recovered by Monte Carlo error propagation. The whiskers in these plots effectively describe the minimum and maximum values of the data, and can also be considered as plausible minimum and maximum values for the median.

\section{RESULTS}

\section{Channel geometries}

Linear relationships between maximum cross-set height and both the mean and the $P_{84}$ cross-set 
height were established from measured cross-set distributions $(n=470)$ for the studied field area (Fig. 5A and B). Maximum and mean cross-set heights are well-correlated $\left(R^{2}=0.88\right)$ and $95 \%$ of observed mean cross-set heights fall within ca $3 \mathrm{~cm}$ of the predicted mean cross-set height. Using these new relationships, mean cross-set heights were estimated for all $(n=4053)$ measured maximum cross-set heights (Fig. 5C to E; Table S3 in Supplementary S4).

Maximum cross-set heights typically span 0.1 to $0.35 \mathrm{~m}$ - these field data are comparable to the results of previous work (e.g. Adams \&
Bhattacharya, 2005). From maximum cross-set heights, mean cross-set heights spanning 0.07 to $0.25 \mathrm{~m}$ are estimated, which correspond with original bedform heights of 0.2 to $0.75 \mathrm{~m}$. Flow depths for the along-depositional-strike transect suggest that, in both space and time, these five transverse fluvial systems maintained median flow depths of 2 to $4 \mathrm{~m}$, with a range of 1 to $7 \mathrm{~m}$ (Fig. 6). Overall, flow depths do not change across the Blackhawk-Castlegate transition but exhibit a marginal decrease during middle Castlegate Sandstone deposition of $<0.5 \mathrm{~m}$. Flow depths are also projected to be overall $<1 \mathrm{~m}$
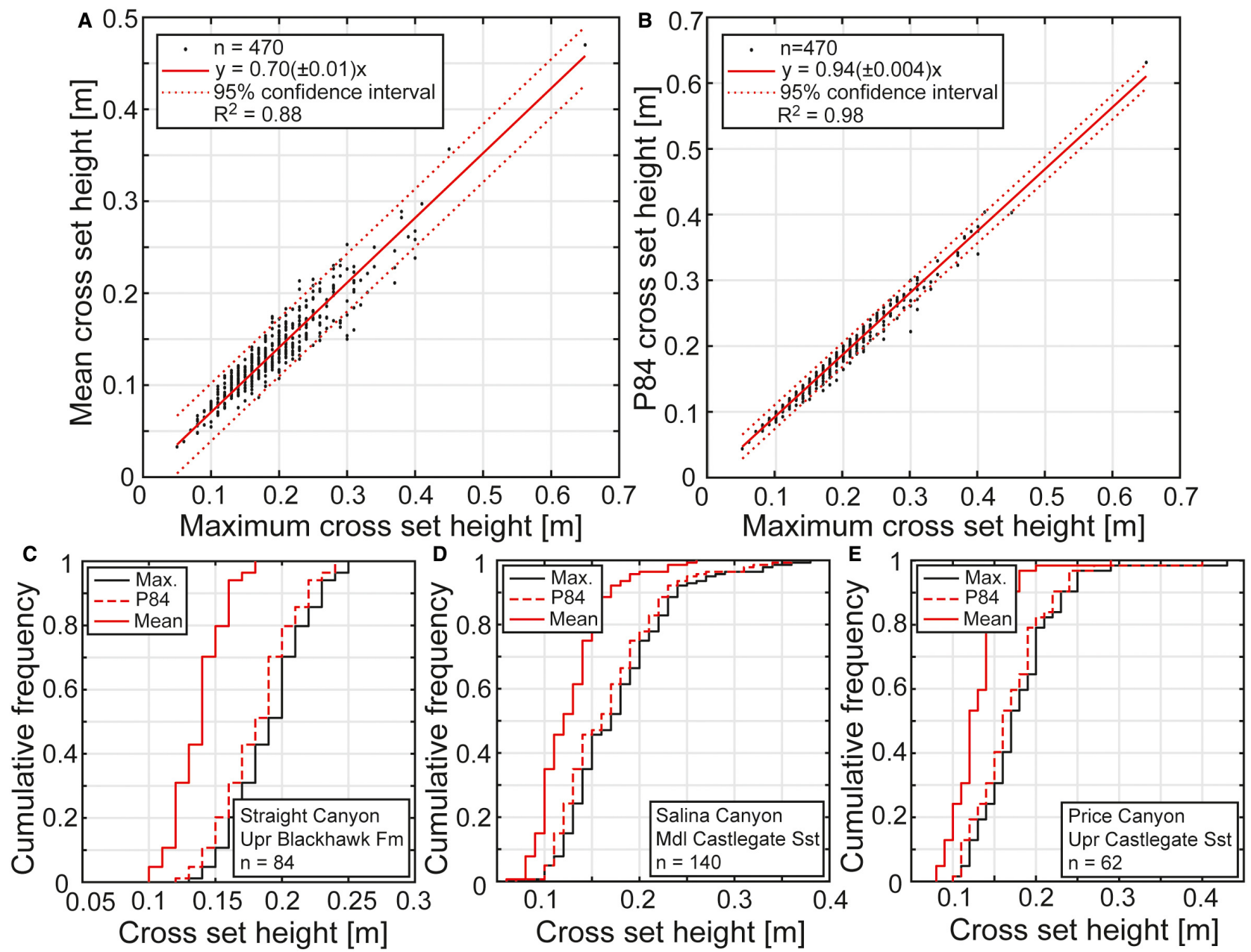

Fig. 5. (A) Relationship between maximum cross-set height and mean cross-set height. (B) Relationship between maximum cross-set height and the $84^{\text {th }}$ percentile $\left(P_{84}\right)$ of cross-set height. Data are based on 470 measured crossset distributions. Errors reported in the fits are 95\% confidence intervals. (C) to (E) Examples of the use of these new relations (parts $\mathrm{A}$ and $\mathrm{B}$ ) to predict the mean and $P_{84}$ cross-set height from maximum cross-set heights. Examples are for the upper Blackhawk Formation in Straight Canyon (C), the middle Castlegate Sandstone in Salina Canyon (D), and the upper Castlegate Sandstone in Price Canyon (E). In (C) to (E), 'n' indicates the number of maximum cross-set heights used to predict mean and $P_{84}$ cross-set heights. Full cross-set data for each field site, through each stratigraphic interval, are located in Table S3 in Supplementary S4. 

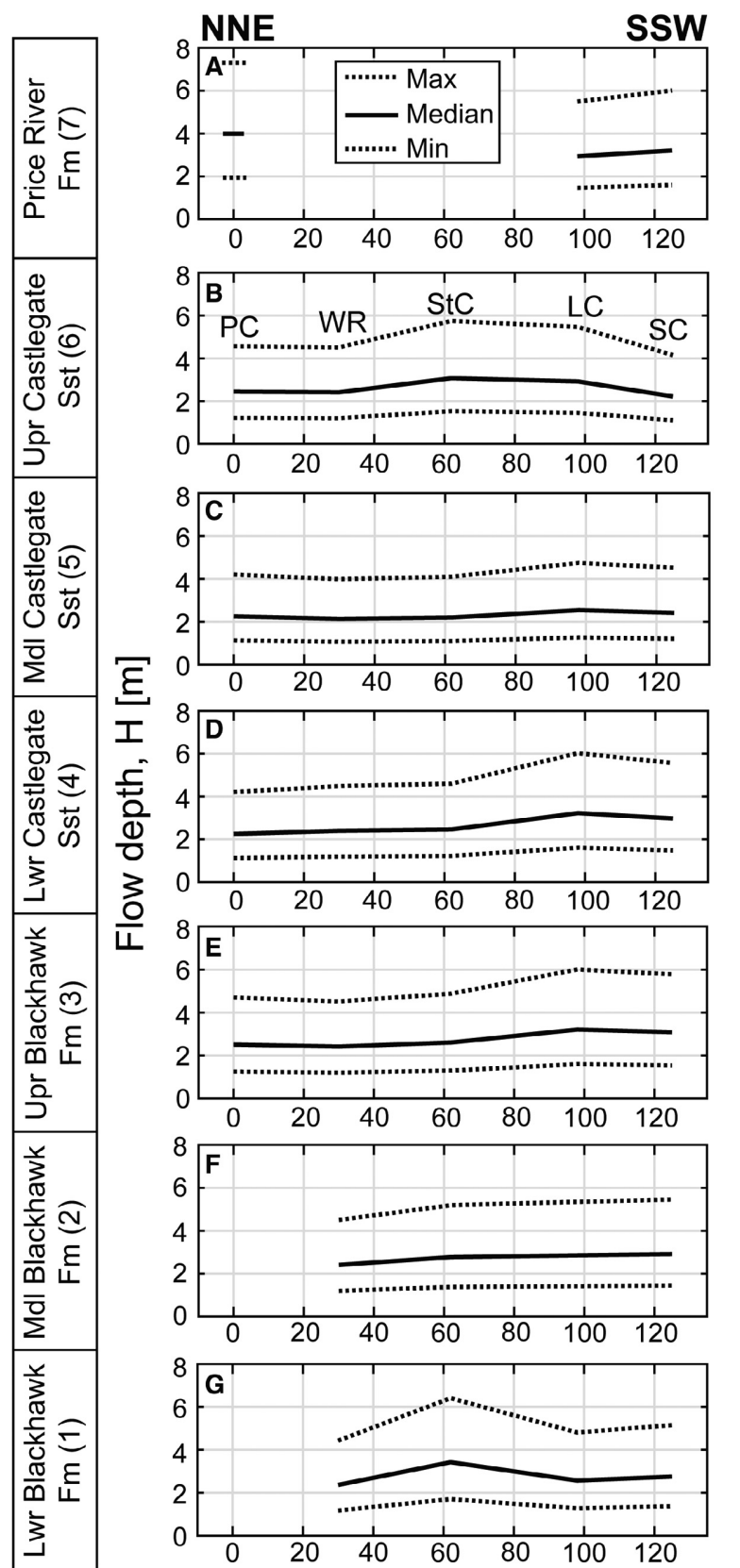

\section{Distance along depositional-strike [km]}

Fig. 6. Reconstructed palaeoflow depths for the five parallel fluvial systems, for each stratigraphic interval (A) to (G), where possible, using mean cross-set heights. Results are presented as along-depositional strike transects from NNE (left; $0 \mathrm{~km}$ ) to SSW (right; $125 \mathrm{~km}$ ). Field sites span Price Canyon (PC), Wattis Road (WR), Straight Canyon (StC), Link Canyon (LC) and Salina Canyon (SC). Solid lines indicate median palaeoflow depths and dashed lines indicated plausible minimum and maximum values for median palaeoflow depths using uncertainty margins of Eq. 2. This figure is replicated in the Supporting Information alongside palaeoflow depths reconstructed from maximum cross-set heights (Fig. S5 in Supplementary S8). greater in southern fluvial systems (Fig. 6). However, these observed differences all lie within the uncertainty margins of calculations, suggesting that these systems were similar to one another.

Reconstructed palaeoflow depths are consistent with independent palaeoflow depth proxies (Table S4 in Supplementary S6), which demonstrates applicability of cross-set scaling relations in the absence of well-preserved macroforms. Bar heights, where available, are consistent with projected flow depths of 2 to $4 \mathrm{~m}$ across field sites. For instance, Chamberlin \& Hajek (2019) reported mean bar heights of $2.6 \mathrm{~m}, 3.6 \mathrm{~m}$ and $3.9 \mathrm{~m}$ for the entire Castlegate Sandstone at Price Canyon, Straight Canyon and Salina Canyon, respectively. At Price Canyon, both Lynds \& Hajek (2006) and Hajek \& Heller (2012) reported greater mean bar heights of $4.1 \mathrm{~m}$ specifically for the lower Castlegate Sandstone, with a typical span of 1 to $8 \mathrm{~m}$ (Lynds \& Hajek, 2006; McLaurin \& Steel, 2007) - the authors note that the full range of our reconstructed palaeoflow depths is typically 1 to $7 \mathrm{~m}$ and therefore agrees with this range. Meanwhile, channelized fluvial sandstone bodies are more extensively documented for the Blackhawk Formation and their heights offer a maximum limit on palaeoflow depths. Flood \& Hampson (2015) recovered mean apparent heights for channelized sandstone bodies of 6 to $8 \mathrm{~m}$ across the entire Blackhawk Formation between Straight Canyon and Salina Canyon. As maximum bounds on palaeoflow depth, these values are also in good agreement with the upper bounds of estimated palaeoflow depths.

\section{Palaeoslopes and river long profiles}

Palaeoslope estimates for the northern (Fig. 7A to F) and southern (Fig. $7 \mathrm{G}$ to $\mathrm{M}$ ) transects and results from each method (Eqs 3 and 4) were compared (Fig. 7). Palaeoslopes are presented as $\mathrm{y} / \mathrm{x}$ - a palaeoslope of 0.001 results in an elevation decrease of $1 \mathrm{~m}$ per $1000 \mathrm{~m}$ and is equivalent to $0.057^{\circ}$. Maximum (up-dip) palaeoslopes of $5 \times 10^{-3}$ are equivalent to slopes of $c a 0.3^{\circ}$; these magnitudes of palaeoslope are comparable with the slopes of modern rivers, including middle-upper reaches of the Colorado (USA) and upper reaches of the Niger (west Africa) (Roberts et al., 2012; Paul et al., 2014; Fernandes et al., 2019). Minimum (down-dip) palaeoslopes of $c a$ $5 \times 10^{-5}$ are equivalent to slopes of $\mathrm{ca} 0.003^{\circ}$; palaeoslopes in the range $10^{-5}$ to $10^{-4}$ are 


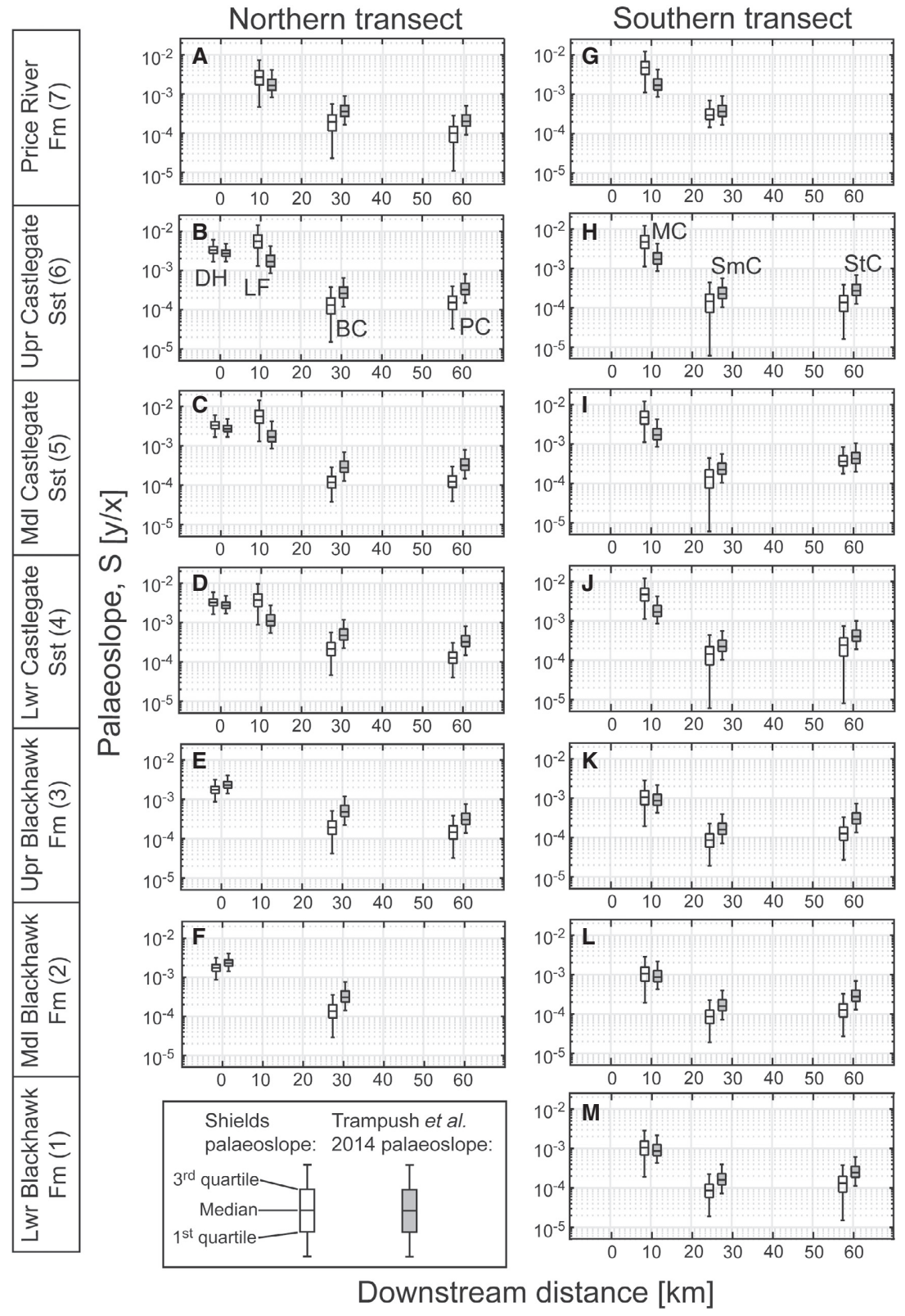

Fig. 7. Up-dip to down-dip palaeoslope estimates for the defined northern and southern transects, using bulk grain-size data, for each stratigraphic interval (1 to 7), where possible. (A) to (F) Represent up-dip to down-dip palaeoslopes for the northern transect, from the middle Blackhawk Formation to the Price River Formation. (G) to (M) Represent up-dip to down-dip palaeoslopes for the southern transect, from the lower Blackhawk Formation to the Price River Formation. The central mark of each box indicates the median estimate, and the bottom and top edges of each box indicate the first and third quartiles (or $25^{\text {th }}$ and $75^{\text {th }}$ percentiles), respectively. The whiskers extend to the most extreme estimates that are not considered to be outliers.

Palaeoslope estimates are derived from two independent approaches; boxes with no fill indicate estimates of palaeoslope derived using a Shields stress inversion (Eq. 3) and boxes with grey fill indicate estimates derived from the method of Trampush et al. (2014) (Eq. 4). $\mathrm{BC}=$ Bear Canyon; $\mathrm{DH}=$ Dry Hollow; LF = Lake Fork; $\mathrm{MC}=$ Mellor Canyon; $\mathrm{PC}=$ Price Canyon; SmC = Sixmile Canyon; $\mathrm{StC}=$ Straight Canyon. characteristic of lowland/low-slope rivers, such as lower reaches of the Mississippi (USA), Ebro (Spain), Nile (north-east Africa) and Murray-Darling (Australia) (Carlston, 1969; Rudge et al., 2015; Fernandes et al., 2019; Roberts et al., 2019; Soria-Jáuregui et al., 2019).

Up-dip, palaeoslopes are consistently of order $10^{-3}$ (Fig. 7), with the exception of the Blackhawk Formation in the southern transect where first to third interquartile range of recovered palaeoslope values extends down to $7 \times 10^{-4}$ (Fig. 7K to M). Importantly, an order of magnitude decrease in palaeoslope is reconstructed between a down-system distance of $10 \mathrm{~km}$ and $25 \mathrm{~km}$; this occurs in all stratigraphic intervals, at the same downstream distance, for both the northern and southern transects (Fig. 7). Downdip, from $\mathrm{ca} 25 \mathrm{~km}$ onward, palaeoslopes are flatter and typically span $5 \times 10^{-5}$ to $5 \times 10^{-4}$. In these lower gradient regions, there is an apparent down-dip increase in palaeoslope in Fig. 7B, C and I to M. However, this apparent increase is within the first to third interquartile range of values and may not be significant. Updip to down-dip palaeoslope estimates derived from Eqs 3 and 4 are broadly consistent with 
Fig. 8. Palaeoslope estimates for the most up-dip location of the defined northern (A) and southern (B) depositional-dip transects, for each stratigraphic interval (1 to 7), where possible, using bulk grainsize data. The central mark of each box indicates the median estimate, and the edges of each box indicate the first and third quartiles (or $25^{\text {th }}$ and $75^{\text {th }}$ percentiles) of estimates. The whiskers extend to the most extreme estimates that are not considered to be outliers.

Palaeoslope estimates are derived from two independent approaches; boxes with no fill indicate estimates of palaeoslope derived using a Shields stress inversion (Eq. 3) and boxes with grey fill indicate estimates derived from the method of Trampush et al. (2014) (Eq. 4).

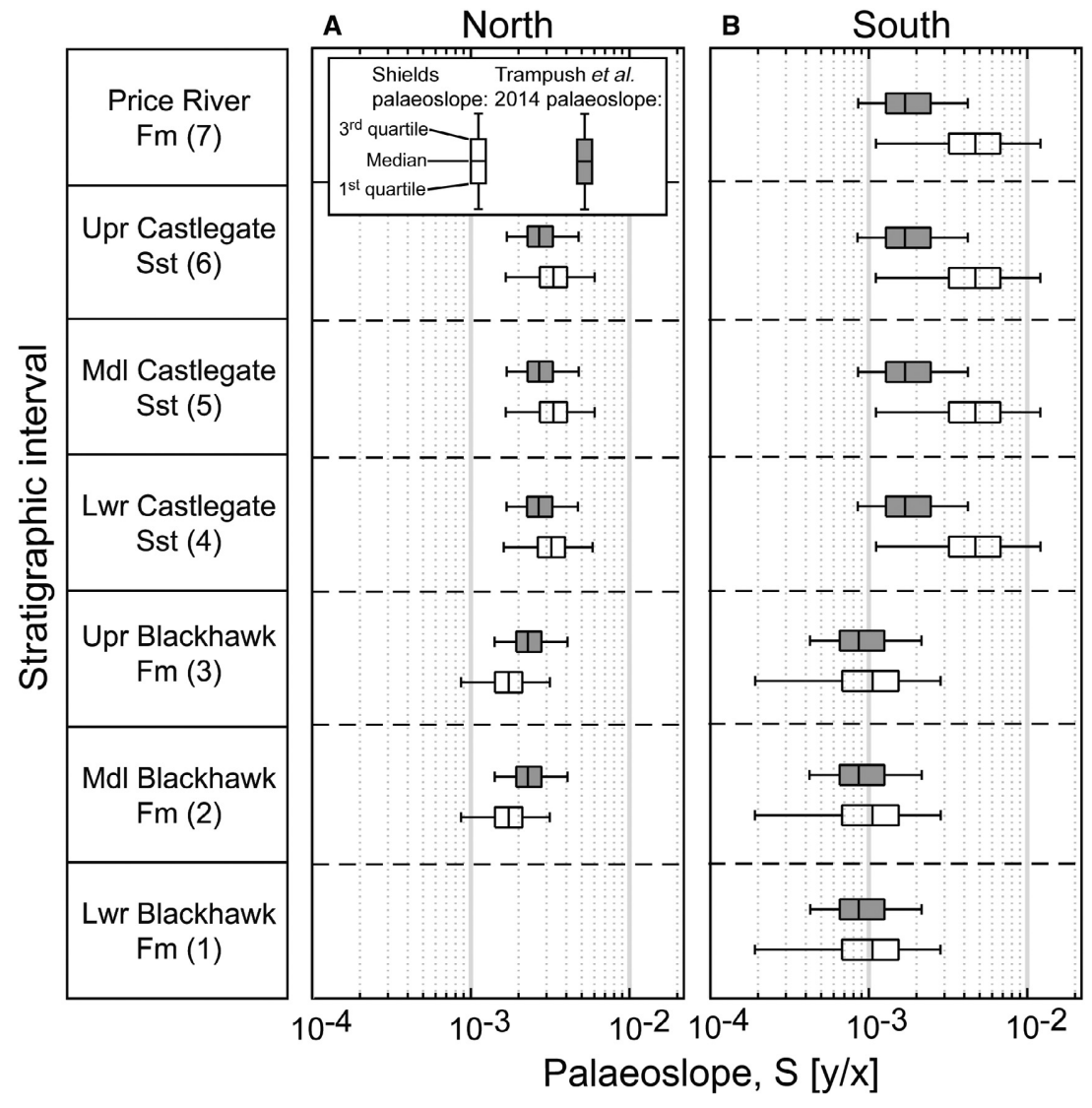

derived from Eq. 4 dampen this increase relative to estimates derived from Eq. 3.

With up-dip to down-dip palaeoslope estimates for both the northern and southern transects, best-fit palaeoslope profiles were derived as a function of downstream distance (Eq. 7; Table S6 in Supplementary S7). Palaeoslope profiles generally fit reconstructed palaeoslopes well, with typical $R^{2}$ values $>0.85$, and it is noted that of three reference concavities, $\theta$, used, the higher value of $\theta=0.6$ typically recovered the best fits (Table S6 in Supplementary S7). A notable exception to this is palaeoslope profiles reconstructed from Shields stress palaeoslope estimates for the Castlegate Sandstone in the northern depositional-dip transect - the lower $\theta=0.4$ value generates the best fit and this fit is relatively poor $\left(R^{2}\right.$ of $\left.0.35-0.6\right)$. However, palaeoslope profiles for these same space-time intervals derived from alternative palaeoslope estimates (Eq. 4) fit well $\left(R^{2}>0.9\right.$; Table S6 in Supplementary S7).

In reconstructing palaeoslope profiles steepness index, $k_{s}$, values were recovered for each stratigraphic interval (for $\theta=0.5$ ), which were 


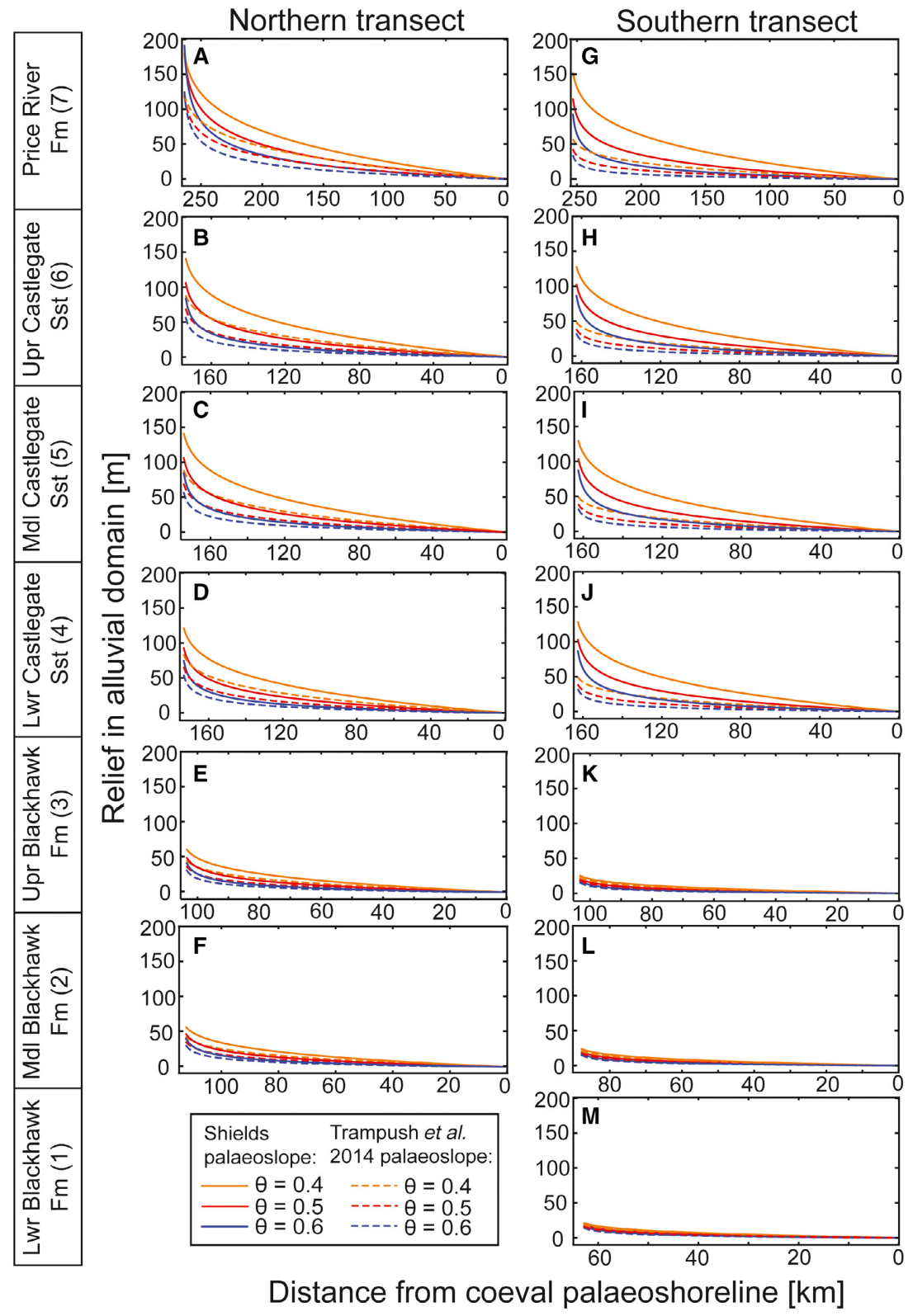

Fig. 9. Estimated palaeorelief in the alluvial domain for the defined northern and southern transects, using bulk grain-size data, for each stratigraphic interval (1 to 7), where possible. (A) to (F) Depict estimated palaeorelief for the northern transect, from the middle Blackhawk Formation to the Price River Formation. (G) to (M) Depict estimated palaeorelief for the lower Blackhawk Formation to the Price River Formation. Palaeorelief estimates are derived using palaeoslope estimates from two independent approaches; palaeoslopes from a Shields stress inversion (Eq. 3) and palaeoslopes from the method of Trampush et al. (2014) (Eq. 4). In addition, palaeorelief is estimated using a plausible range of values for the concavity index, $\theta$. Unlike other depositional-dip transects in this study, the $x$ axis instead depicts distance from the coeval palaeoshoreline (following Hettinger \& Kirschbaum, 2002; Hampson et al., 2012; Hampson et al., 2013). mostly between $c a 5 \mathrm{~m}$ and $35 \mathrm{~m}$ (Table S6 in Supplementary S7). There is an increase in reconstructed $k_{s}$ values across the Blackhawk-Castlegate transition for both methods of palaeoslope estimation. For estimates derived from Eq. $3, k_{s}$ values increase across the Blackhawk-Castlegate transition by a factor of $c a 2$ to 3 in the northern transect, and by a factor of $\mathrm{Ca} 4$ to 5 in the southern transect. In contrast, for estimates derived Eq. $4, k_{s}$ values increase across the Blackhawk-Castlegate transition by a factor of $<1.5$ in the northern transect, and by a factor of $c a 2$ in the southern transect (Table S6 in Supplementary S7).
Palaeoslope profiles were transformed into river long profiles, which are indicative of the palaeorelief in the alluvial domain, or depositional reaches, of Blackhawk-Castlegate-Price River fluvial systems only (Fig. 9). Given that the concavities of these ancient rivers are not known, implementing plausible concavities of $0.4,0.5$ and 0.6 enabled a likely spread of values for palaeorelief to be constrained (Fig. 9). Results indicate that different concavities recover similar values for palaeorelief; total estimates vary within a factor of $c a 2$, between a concavity of 0.4 and 0.6 (Fig. 9). 
Using palaeoslope estimates derived from Eq. 3, palaeorelief during Blackhawk deposition was estimated as $c a 40$ to $60 \mathrm{~m}$ in the northern transect (Fig. 9E and F) and 15 to $25 \mathrm{~m}$ in the southern transect (Fig. 9K to M). During Castlegate Sandstone deposition, palaeorelief increased by a factor of 1.5 to 2.5 in the northern transect, to an estimated 65 to $145 \mathrm{~m}$ of palaeorelief, whereas it increased by a factor of 5 to 6 in the southern transect, to an estimated 90 to $130 \mathrm{~m}$ of palaeorelief. Alternatively, using palaeoslope estimates derived from Eq. 4, palaeorelief during Blackhawk Formation deposition was estimated as $c a 30$ to $50 \mathrm{~m}$ in the northern transect (Fig. 9E and $\mathrm{F}$ ) and 15 to $25 \mathrm{~m}$ in the southern transect (Fig. 9K to M). During Castlegate Sandstone deposition, palaeorelief increased by a factor of ca 1.8 in the northern transect, to an estimated 55 to $90 \mathrm{~m}$ of palaeorelief, whereas it increases by a factor of 2 in the southern transect, to an estimated 30 to $50 \mathrm{~m}$ of palaeorelief. In detail, palaeorelief implied by Eq. 3 (Shields) is up to a factor of 2 greater than the palaeorelief implied by Eq. 4 (Trampush). This higher palaeorelief during Castlegate Sandstone deposition is sustained into Price River Formation times. It is stressed that these estimates refer to the alluvial domain only.

\section{Hydrodynamics and sediment transport}

Median flow velocities of $0.8 \mathrm{~m} \mathrm{~s}^{-1}$, with a median plausible range of 0.4 to $1.6 \mathrm{~m} \mathrm{~s}^{-1}$, are deduced across all field data (Fig. 10A), as well as median unit discharges of $2.5 \mathrm{~m}^{2} \mathrm{~s}^{-1}$ with a median plausible range of 1 to $10 \mathrm{~m}^{2} \mathrm{~s}^{-1}$ (Fig. 10B). Using plausible single-thread channel widths of 100 to $500 \mathrm{~m}$ at down-dip locations (see Planform morphologies section), this would imply median total discharges between 250 and $1250 \mathrm{~m}^{3} \mathrm{~s}^{-1}$, which is comparable with total discharges of well-known North American rivers such as the Platte, Hudson, Colorado, Arkansas and Susquehanna. However, if multi-thread rivers are assumed to possess $>1 \mathrm{branch} / \mathrm{braid}$, total discharges would have been several times greater. With a reconstructed increase in palaeoslope at the Blackhawk-Castlegate transition, a coeval increase in flow velocities and unit water discharges is expected analytically. Here, across all up-dip field areas, flow velocities are overall greater during Castlegate Sandstone deposition, up to a factor of 2 to 3 (Fig. 10C), relative to Blackhawk Formation deposition, whereas down-dip flow velocities are broadly the same through time
(Fig. 10D). Both up-dip and down-dip, unit water discharges overall do not change at the Blackhawk-Castlegate transition (Fig. 10E and F). To offer a specific example for the Blackhawk-Castlegate transition (intervals 3 and 4), at Mellor Canyon, median flow velocity, $U$, increased from 1.9 to $3.0 \mathrm{~m} \mathrm{~s}^{-1}$, and median unit water discharge, $Q$, only increased marginally from 4.4 to $4.6 \mathrm{~m}^{2} \mathrm{~s}^{-1}$.

Reconstructed Rouse numbers, $Z$, indicate that dominant transport modes of bed-material varied in space and time (Fig. 11). Up-dip field sites consistently exhibit high $Z$ values for both the median and first to third interquartile range, indicating predominant bedload transport (Fig. 11). Median $Z$ values then decrease by a downstream distance of $30 \mathrm{~km}$, indicating local transition to predominantly mixed load systems, however the likely spread of values indicated by the interquartile ranges implies that dominant transport modes at this downstream distance may have spanned both mixed load and a near entirely suspended load (Fig. 11). A crucial exception to this observation is for Castlegate Sandstone deposition in the southern transect (intervals 4 to 6) where, at a downstream distance of $30 \mathrm{~km}$, median $Z$ values suggest that bedload remains the most important transport mode (Fig. $11 \mathrm{G}$ to I). At downstream distances associated with the most down-dip field sites, median $Z$ values have further decreased; however first to third interquartile ranges mostly still span both the mixed load and entirely suspended load domains.

The inferred dominant sediment transport modes are corroborated with results in Fig. 12, in which Shields stress, $\tau^{*}$, is plotted as a function of particle Reynolds number, $R e_{p}$, for each field site. These data are plotted alongside observed data that are characteristic of suspended load, mixed load and bedload regimes (Leopold \& Wolman, 1957; Schumm, 1968; Chitale, 1970; Church \& Rood, 1983; Andrews, 1984). Up-dip field sites (Dry Canyon, Lake Fork and Mellor Canyon) plot among secondary data that are typical for bedload rivers, meanwhile all other field sites plot in the mixed-load realm (Fig. 12). Of field sites dominated by a mixed load, data from Sixmile Canyon and Straight Canyon plot closest to the bedload realm, which is consistent with observations in Fig. 11, where results suggest that bedload transport remained important in the southern transect during Castlegate Sandstone deposition (intervals 4 to 6). Overall, results in Fig. 12 suggest that, down-dip, field sites are firmly in the mixed load range - it is unlikely 

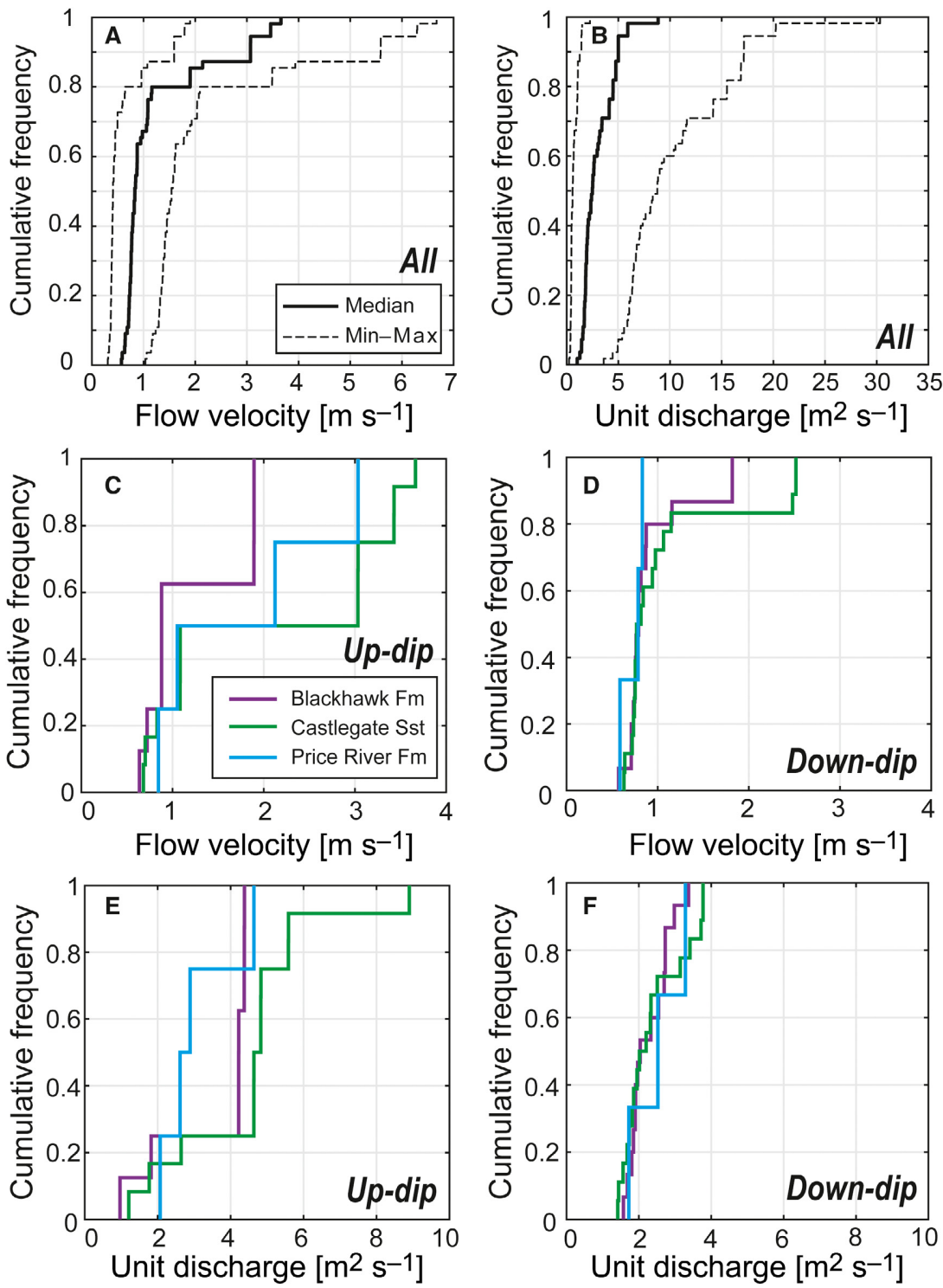

Fig. 10. Cumulative frequency distributions of: (A) reconstructed flow velocities across all field areas; and (B) reconstructed water discharges, per unit width, across all field areas. Solid lines indicate median values and dashed lines indicate plausible minimum and maximum values for the median, derived from propagated uncertainty margins. Flow velocities are derived using Manning's formula (Eq. 7), as described in the Methods section. (C) to (F) Depict flow velocities and unit water discharges split into up-dip and down-dip field sites. Down-dip field areas include field areas on the along-strike depositional transect (Price Canyon, Wattis Road, Straight Canyon, Link Canyon and Salina Canyon), meanwhile up-dip field areas include all those that are relatively up-dip (Dry Hollow, Lake Fork, Bear Canyon, Mellor Canyon, Sixmile Canyon). Field areas were also split into the Blackhawk Formation (and up-dip equivalents, i.e. intervals 1 to 3), Castlegate Sandstone (and up-dip equivalents, i.e. intervals 4 to 6) and Price River Formation (and up-dip equivalents, i.e. interval 7). (C) and (D) Depict cumulative frequency distributions of reconstructed flow velocities for up-dip (C) and down-dip (D) field areas, respectively. (E) and (F) Depict cumulative frequency distributions of reconstructed unit water discharges for up-dip (E) and down-dip (F) field areas, respectively.

that bed-material loads were predominantly suspended. In contrast, the first to third interquartile ranges in Fig. 11 suggest that dominant sediment transport modes may have spanned the mixed load/predominantly suspended domain. Downdip, all field sites straddle the bounds between 
Fig. 11. Estimated Rouse numbers, $Z$, for the defined northern and southern transects, using bulk grainsize data, for each stratigraphic interval (1 to 7 ), where possible. Dominant mode of sediment transport is typically wash load for $Z<0.8,100 \%$ suspended load for $0.8<Z<1.2,50 \%$ suspended load (i.e. mixed load) for $1.2<Z<2.5$, and bedload for $Z>2.5$. (A) to (E) Represent up-dip to down-dip Rouse numbers for the northern transect, from the upper Blackhawk Formation to the Price River Formation. (F) to (L) Represent updip to down-dip Rouse numbers for the southern transect, from the lower Blackhawk Formation to the Price River Formation. The central mark of each box indicates the median estimate, and the bottom and top edges of each box indicate the first and third quartiles (or $25^{\text {th }}$ and $75^{\text {th }}$ percentiles), respectively. The whiskers extend to the most extreme estimates that are not considered to be outliers. Dashed red lines indicate the bounds between differing dominant sediment transport modes, as labelled in (A).

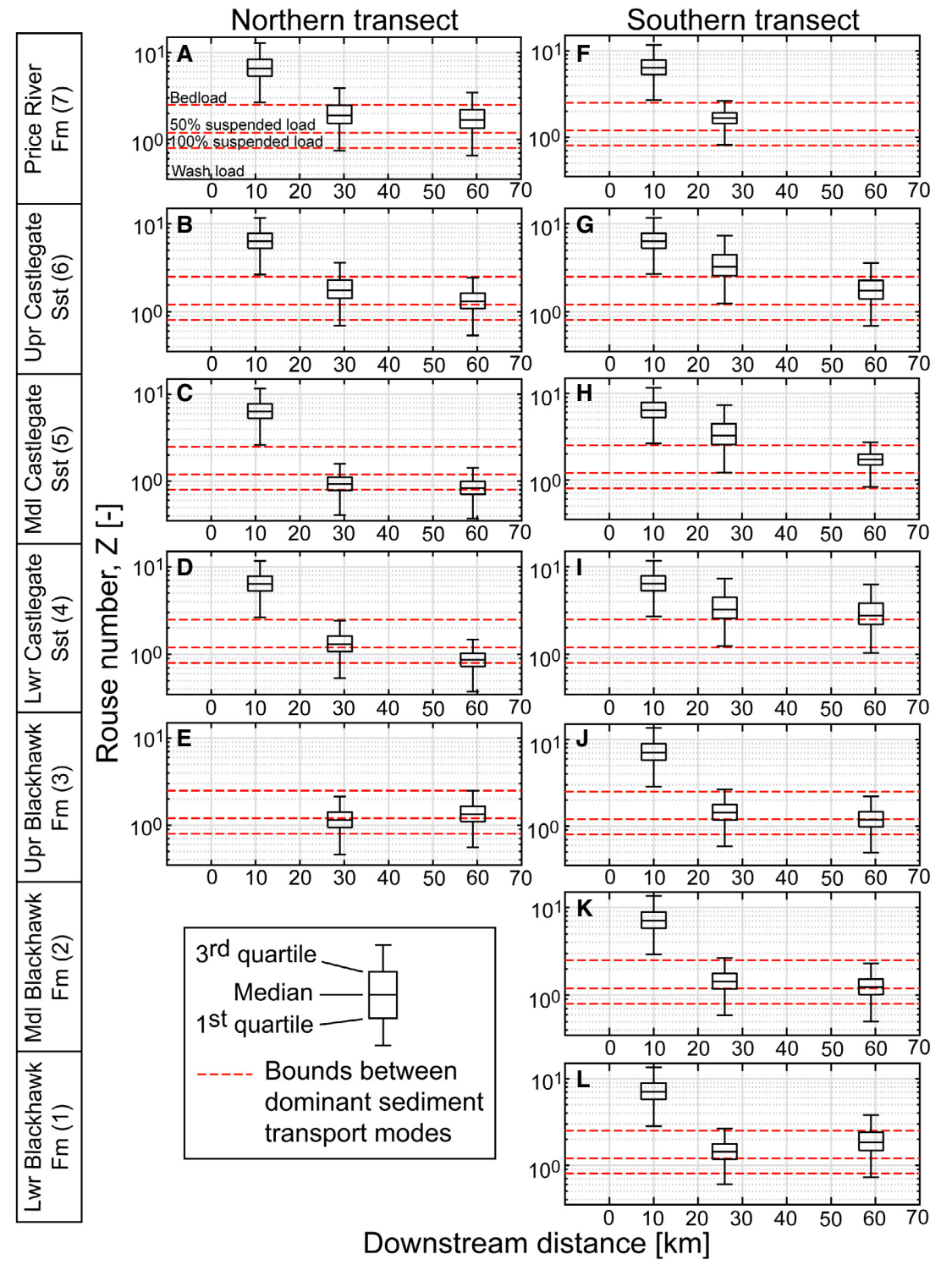

the stability fields for ripples and dunes and upper-stage plane beds (Fig. 12), which implies unidirectional flow and high sediment transport rates (both suspended transport and bedload transport).

\section{Planform morphologies}

Finally, these data provide insights into the implied planform morphology of these ancient fluvial systems. However, to do this effectively estimates of palaeochannel widths are needed. Widths are difficult to constrain with confidence from field observations, and estimates from empirical scaling relations are tentative. Assuming single-thread channels, reconstructed median flow depths of 2 to $4 \mathrm{~m}$ might suggest channel widths of order 30 to $110 \mathrm{~m}$ and, using the upper bound of the 1 to $7 \mathrm{~m}$ range, widths up to $c a 300$ $m$ (following Bridge \& Mackey, 1993). In contrast, if multi-thread channel belts are assumed, then channel belt widths of order 90 to $200 \mathrm{~m}$, and up to $c a 400 \mathrm{~m}$, might be expected (following Leopold \& Maddock Jr, 1953).

For a range of possible widths, palaeoslope/ Froude ratios were plotted against channel depth/ width ratios (cf. Parker, 1976a; Ganti et al., 2019b) (Fig. 13). Results imply that, for Blackhawk-Castlegate-Price River fluvial systems, singlethread planforms would be stable at channel widths $<1 \mathrm{~km}$; channel and channel-belt widths $>1 \mathrm{~km}$ would have been required to instigate 


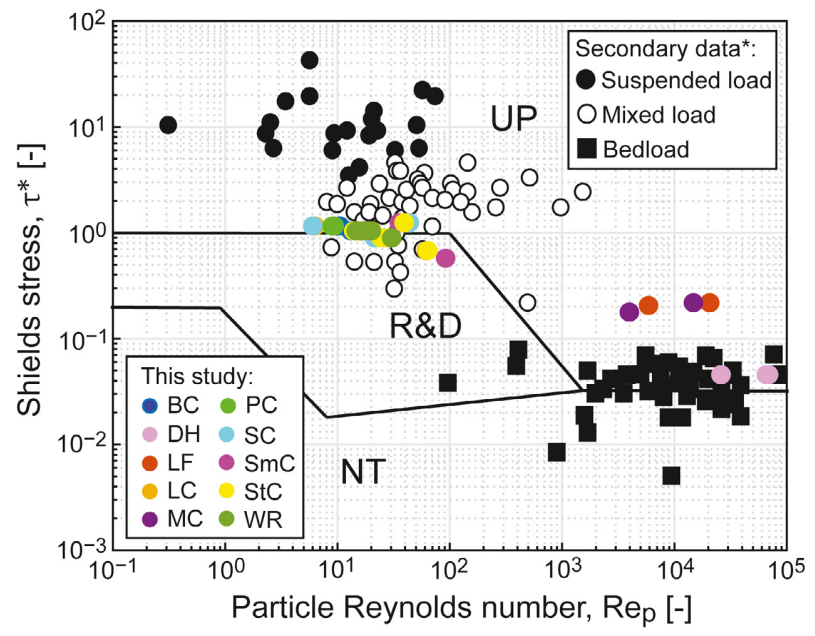

Fig. 12. Shields stress, $\tau^{*}$, plotted as a function of particle Reynold's number, $R e_{p}$, for all field sites and for each stratigraphic interval ( 1 to 7 ), where possible, using bulk grain-size data. Colour-filled circles indicate field results from this study for Bear Canyon (BC), Dry Hollow (DH), Lake Fork (LF), Link Canyon (LC), Mellor Canyon (MC), Price Canyon (PC), Salina Canyon (SC), Sixmile Canyon (SmC), Straight Canyon (StC) and Wattis Road (WR). *For comparison, this plot includes secondary data, originally compiled by Dade \& Friend (1998), from Leopold \& Wolman (1957); Schumm (1968); Chitale (1970); Church \& Rood (1983); Andrews (1984), for characteristic dominant transport modes. Black squares indicate bedload, white circles indicate mixed load and black circles indicate suspended load. Solid black lines indicate stability fields of different flow regimes: no sediment transport (NT), ripples and dunes (R\&D) and upperstage plane beds (UP), in line with Allen (1982a, 1982b).

formation of bars and support transition to multithread systems, forming vast channel-belt complexes (Fig. 13A to D). However, planform reconstructions are very dependent on grain size, a factor which is often not evaluated systematically. Bulk grain sizes were used in initial calculations (Fig. 13A to D; see Methods section). However, when using gravel-fraction grain sizes, which can be associated with tectonic or climatic perturbations (for example, increased palaeoslope or highmagnitude low-frequency discharge events), the results show that multi-thread planforms were more likely (Fig. 13E to H). For gravel-fraction grain sizes, results imply that single-thread planforms were likely stable at channel widths $<500 \mathrm{~m}$, and that channel and channel-belt widths $>500 \mathrm{~m}$ would have supported transition to multithread systems (Fig. 13B).
Of the Blackhawk-Castlegate-Price River fluvial systems, field results for the Castlegate Sandstone plot closest to the singlethread-multi-thread transition, whereas field results for the Price River Formation plot furthest from this transition (Fig. 13). This indicates the relatively high propensity of Castlegate fluvial systems to braiding, relative to Blackhawk and Price River systems.

\section{DISCUSSION}

\section{What did Campanian palaeorivers look like?}

These analyses provide new insights that build on previous work characterizing ancient rivers in the Campanian of central Utah as a series of distinct parallel transverse systems draining the Sevier front (Robinson \& Slingerland, 1998; Bartschi et al., 2018; Chamberlin \& Hajek, 2019; Pettit et al., 2019). These rivers traversed a lowgradient landscape; alluvial relief was tens of metres to $c a 100 \mathrm{~m}$, and the length scale of the alluvial domain (i.e. the distance from fan apexes to the palaeoshoreline) varied from as little as $c a 70 \mathrm{~km}$ during lower Blackhawk Formation deposition, up to and in excess of $250 \mathrm{~km}$ during Price River Formation deposition (Hettinger \& Kirschbaum, 2002; Aschoff \& Steel, 2011a; Hampson et al., 2012; Hampson et al., 2013). Relief was tens of metres during Blackhawk deposition, when the length scale of the alluvial domain was at its narrowest. At the onset of Castlegate Sandstone deposition an increase in palaeoslope is documented, with palaeorelief increasing to $c a 100 \mathrm{~m}$, which persisted into Price River deposition (Figs 7 to 9). For comparative purposes, such values of palaeoslope and palaeorelief are characteristic of the Mississippi River and downstream reaches of its principal tributaries, for example the Missouri, Tennessee, Arkansas and Red rivers (Carlston, 1969; Fernandes et al., 2019).

Results imply that palaeoriver morphologies were similar in space and time, with palaeoflow depths of order 2 to $4 \mathrm{~m}$ (Fig. 6). Previous detrital zircon results suggest that northerly field sites (Price Canyon and Wattis Road) represent smaller transverse systems and that southerly field sites (Straight Canyon, Link Canyon and Salina Canyon) represent larger systems that include a longitudinal drainage component (Bartschi et al., 2018; Pettit et al., 2019). These results indicate that size disparities between 
Fig. 13. Theoretical stability fields of fluvial planform morphologies, i.e. single-thread and multi-thread planforms, for both bulk grain sizes (A) to (D) and gravel fraction grain sizes $(\mathrm{E})$ to $(\mathrm{H})$, where present (not all field localities possessed a gravel fraction). For both bulk and gravel grain-size fractions, a range of river widths are assumed $(500 \mathrm{~m}, 1 \mathrm{~km}$, $2 \mathrm{~km}$ and $3 \mathrm{~km}$ ) and used to calculate the depth/width ratio. Data points are for all localities, in space and time, along the defined along-depositional strike transect, i.e. these data points represent the five parallel fluvial systems and do not consider up-dip localities. Data are further subdivided into the Blackhawk Formation (intervals 1 to 3), Castlegate Sandstone (intervals 4 to 6) and Price River Formation (interval 7). Coloured markers indicate the median value, and error bars represent plausible minimum and maximum values for the median, derived from propagated uncertainty margins. Solid black lines indicate the bounds of each stability field, and therefore the predicted transition from single-thread (straight/ meandering) to multi-thread (anabranching/braided) planform morphology. Dashed black lines indicate a potential transition from 1 to 10 threads to $>10$ threads, based on modern data (Parker, 1976).

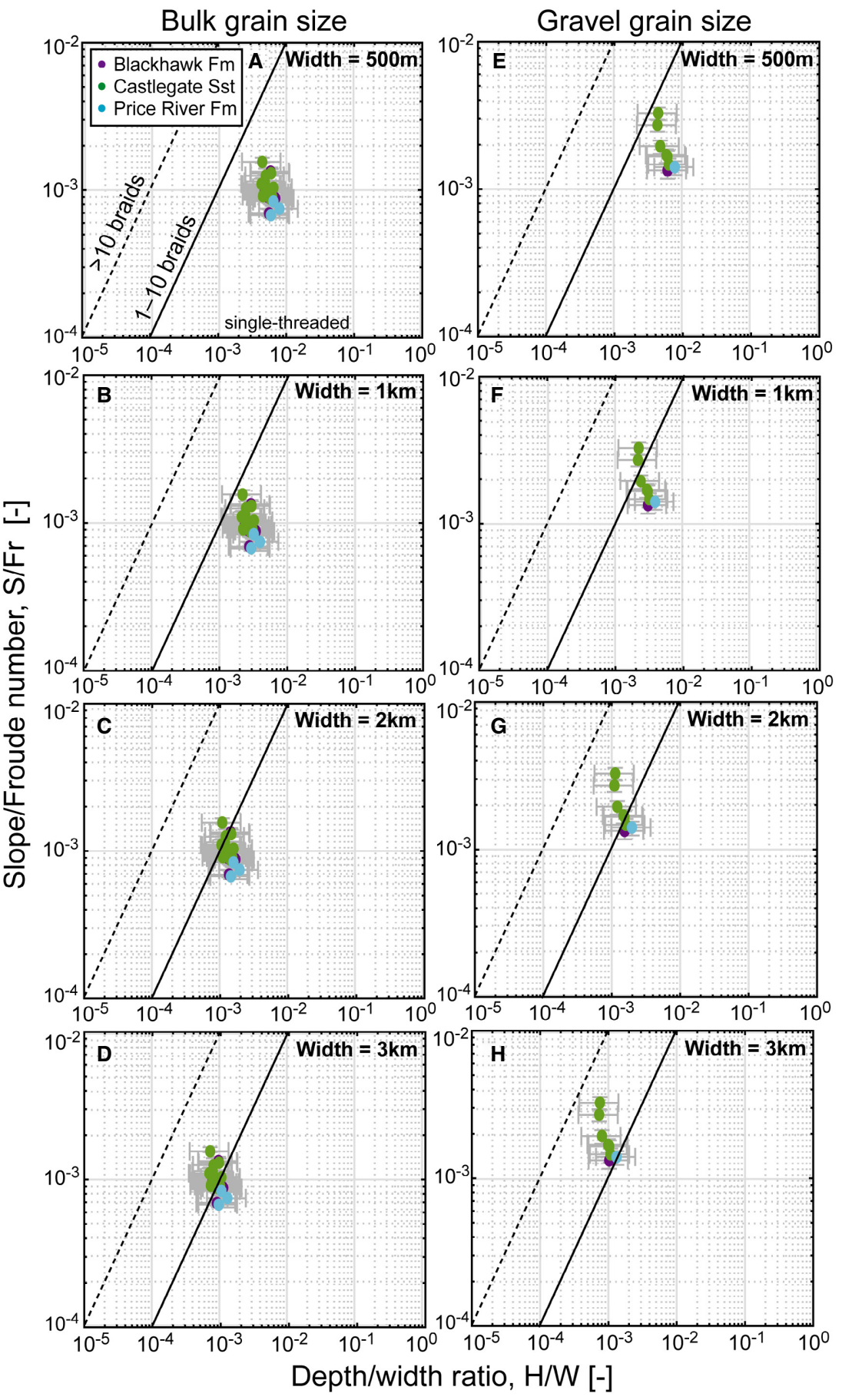

these five systems were not statistically significant - reconstructed variations in palaeoflow depths are within the full range of plausible values. However, palaeoflow depths appear to have been marginally greater in southerly systems (Fig. 6). If true, this may be attributed to the possible longitudinal drainage component (Bartschi et al., 2018; Pettit et al., 2019).
Comparisons with modern rivers suggest that these five parallel palaeorivers (being $c a 25 \mathrm{~km}$ apart) were substantial systems. Reconstructed hydrodynamic properties, such as flow velocities and unit water discharges, are consistent with the ranges of values of modern systems with similar outlet spacings and similar distances to range fronts (Perry et al., 1996; Schulze et al., 2005; 
Milliman \& Farnsworth, 2013; Global Runoff Data Centre). Notably, unit discharges are overall constant in time - there is no apparent increase in unit discharge at the Blackhawk-Castlegate transition (coeval with palaeoslope increase). This raises questions as to the nature of down-system width evolution and has implications for total discharge - plausible single-thread river widths of 100 to $500 \mathrm{~m}$ at down-dip locations would imply median total discharges of 250 to $1250 \mathrm{~m}^{3} \mathrm{~s}^{-1}$.

Bedload transport was dominant at graveldominated up-dip localities, as expected, and suspended-load and mixed-load systems prevailed further down-dip, with some localized variations (Figs 11 and 12). For example, results highlight the importance of bedload transport during Castlegate Sandstone deposition in the southern transect (Figs 11 and 12). With this information it is possible to map out how river behaviour varied spatially within catchments, and this informs best practices when it comes to reconstructing sediment discharges. This is especially important when interested in reconstructing the entire sediment load of an ancient system. For instance, channel palaeohydrological approaches are often used to reconstruct sediment discharges in ancient source-to-sink systems (Holbrook \& Wanas, 2014; Lin \& Bhattacharya, 2017; Sharma et al., 2017); however these reconstruction tools solely reconstruct the bedload fraction and the suspended fraction of the bed material load (van Rijn, 1984b; Wright \& Parker, 2004), i.e. the portion of the suspended load that interacts with the bed. As such, these reconstruction tools are not appropriate, by themselves, for reconstructing the total sediment load of a wash load-dominated system, for example. Knowledge of prevailing sediment transport modes is important for evaluating whether different sediment discharge reconstruction methods are consistent with one another, because studies that reconstruct sediment discharges often corroborate results with an independent approach (Lin \& Bhattacharya, 2017; Watkins et al., 2018; Zhang et al., 2018; Brewer et al., 2020; Lyster et al., 2020).

Here, reconstructions of planform morphology, following Parker (1976a), and assuming channel widths $<1 \mathrm{~km}$, imply that single-thread rivers would have prevailed throughout Blackhawk-Castlegate-Price River deposition. Localized or intermittent transitions to braided planforms may have been associated with tectonic or climatic perturbations, such as increased palaeoslope or high-magnitude, low-frequency discharge events (Fig. 13). In detail, these perturbations (which can be associated with the gravel-fraction grain size) can support braiding at narrower channel/channel-belt widths of order $500 \mathrm{~m}$. Of these fluvial systems, Castlegate systems had a higher propensity to braiding. At this point, it is important to highlight that traditional bipartite classification of fluvial systems aims to define fluvial systems as either straight/ meandering or braided/anabranching end members (Leopold \& Wolman, 1957). However, these are not mutually exclusive; both straight/meandering and braided/anabranching planforms can co-exist at reach scales. These reconstructions can be contextualized by field evidence; however, field observations point to a discrepancy and this topic is returned to in the final Discussion section.

To create a holistic view as to the nature of these ancient fluvial landscapes, various modern analogues can be considered. In the Amazon basin, several of the most up-system tributaries axially drain the central and eastern Andean cordillera. For example, the Huallaga River, Peru, is an axial river fed by transverse systems draining the eastern Andean range front. These transverse rivers have regular outlet spacings, channel-belt widths of order hundreds of metres (up to $1 \mathrm{~km}$ ), and combine both single-thread and multi-thread planforms which vary at reachscales. In the eastern Himalayas, transverse systems draining the range front into the axial Brahmaputra (Assam Valley) provide another modern analogue for the pattern and style of these ancient fluvial systems, despite the larger scale of this system.

\section{What drove spatio-temporal changes in morphological properties?}

A key result in this study is quantification of an increase in palaeoslope at the Blackhawk-Castlegate transition by a factor of 1.5 to 4.0 , as well as the associated increase in palaeorelief (Figs 7 to 9). Increased palaeoslopes have implications for the morphological and hydrodynamic properties of these palaeorivers, including their flow velocities and unit discharges. In this study, the increase in palaeoslope and palaeorelief implies that rivers were actively responding to changes in uplift rate in the hinterland region.

At the Blackhawk-Castlegate transition, palaeorelief increased from tens of metres to $\mathrm{Ca} 100 \mathrm{~m}$ (Fig. 9). An important point to remember is that these estimates are specific to the alluvial domain 
only. Behind the Sevier front, existence of a highelevation plateau known as 'Nevadaplano' is inferred (Allmendinger, 1992; DeCelles, 1994, 2004; DeCelles \& Coogan, 2006), which has been likened to the modern high-elevation plateau, Altiplano, of the central Andes. Palaeoelevations in the Sevier highlands and Nevadaplano are argued to be 3 to $>4 \mathrm{~km}$ - these values have been deduced from a combination of climate modelling studies (Sewall \& Fricke, 2013; Foreman et al., 2015), kinematic reconstructions (DeCelles, 1994, 2004; DeCelles \& Coogan, 2006) and other data, including palaeoflora (Chase et al., 1998). Here, alluvial palaeorelief of order $100 \mathrm{~m}$ is reconstructed. Given that the low-lying alluvial domain of these palaeorivers has a length scale of order 70 to $250 \mathrm{~km}$, and given the proximity to high-elevation Sevier highlands, the entire river long profile is inferred to have likely been highly concave. This is supported in part by the fact that, in reconstructing palaeoslope profiles, the best fits were recovered when using a higher reference concavity of 0.6 (Table S6 in Supplementary S7). If best-fit palaeoslope profiles were projected up-dip into the Sevier hinterland, palaeoslopes of $10^{-1}$ might be reached within as little as $10 \mathrm{~km}$ of the most up-dip field area, and therefore elevations in excess of $1 \mathrm{~km}$ might be reached within a further $10 \mathrm{~km}$. To again use the modern Andes as an analogue, a longitudinal river profile from the Peruvian shoreline to the western Andean cordillera and Altiplano would have a length scale of 50 to $150 \mathrm{~km}$, with 0.5 to $1.0 \mathrm{~km}$ of relief in the alluvial domain and elevations $>3 \mathrm{~km}$ in the western cordillera and Altiplano. With a similar tectonogeographic setting in Late Cretaceous Utah, this comparison can also be used to highlight the potential high concavity of these ancient river profiles.

In reconstructing palaeorelief, steepness indexes, $k_{\mathrm{s}}$, were also recovered for northern and southern transects (Eqs 5 and 6) (Table S6 in Supplementary S7). While $k_{\mathrm{s}}$ was solved for using field data and a nonlinear least squares regression, $k_{s}$ values are often estimated (albeit tenuously) as a function of known uplift rate and erodibility in bedrock channels, but additionally (although less frequently) in downstream alluvial reaches (Kirby \& Whipple, 2012; Pederson \& Tressler, 2012; Stucky de Quay et al., 2019). Inversely, where $k_{s}$ can be measured, and where erodibility is known, first-order estimates of uplift rate can be made. Steepness indexes recovered in this study were typically $c a 5$ to $35 \mathrm{~m}$ (for a reference concavity, $\theta$, of 0.5 ) and, despite unknown erodibility, global data compilations indicate that low uplift rates of order 0.01 to $0.1 \mathrm{~mm} \mathrm{yr}^{-1}$ are generally associated with these kinds of values (Kirby \& Whipple, 2012). Despite overall low $k_{s}$ values, it is important to note the relative increase in $k_{s}$ by a factor of $<1.5$ to 5.0 at the Blackhawk-Castlegate transition. While these are first-order estimates, and are derived solely for the alluvial domain, an increase in $k_{s}$ (and palaeorelief) can be attributed to a relative increase in uplift rate in the hinterland region. Here, this increase might be attributed to frontal thrust migration, or thrust initiation in the Sevier highlands (DeCelles, 2004; DeCelles \& Coogan, 2006). This includes Sevier shortening in the Charleston-Nebo Salient (CNS), an eastward convex portion of the Sevier thrust front in northcentral Utah (Fig. 1B) (Bruhn et al., 1986; Bryant \& Nichols, 1988; Constenius et al., 2003; Bartschi et al., 2018), which is commonly attributed to the influx of quartzite-dominated coarse-grained detritus associated with Castlegate Sandstone progradation (Robinson \& Slingerland, 1998; Horton et al., 2004). For Castlegate Sandstone deposition in the northern transect, results show that palaeoslope profiles did not fit reconstructed palaeoslopes well and favoured lower concavities (which also did not fit well). The interpretation herein is that shortening in the CNS, which has been structurally linked with coeval basement Laramide uplifts in northern Utah (Bruhn et al., 1986; Bryant \& Nichols, 1988; Constenius et al., 2003; Bartschi et al., 2018), may have significantly influenced river long profiles associated with northerly Castlegate fluvial systems near Price, and locally lowered their concavities. Whereas ca $60 \mathrm{~km}$ south in the southern transect, higher concavity values of 0.6 deliver best fitting palaeoslope profiles through all seven stratigraphic intervals (Table S6 in Supplementary S7).

While tectonic drivers are commonly attributed to variations in channel steepness (Kirby \& Whipple, 2001; Kirby et al., 2003; Wobus et al., 2006; Boulton \& Whittaker, 2009; DiBiase et al., 2010), climatic drivers, especially precipitation rates, also play a crucial role but are notoriously difficult to disentangle from their tectonic counterpart (Wobus et al., 2010; DiBiase \& Whipple, 2011; Champagnac et al., 2012; Whittaker, 2012; D'Arcy \& Whittaker, 2014). The role of climate is important to consider here, given the assumed monsoonal climate and, therefore, highly seasonal discharge variability (Roberts, 2007; Roberts et al., 2008; Fricke et al., 2010; Sewall \& Fricke, 
2013). Previous work shows that precipitation rates have a discernible role on steepness indexes (Champagnac et al., 2012; D'Arcy \& Whittaker, 2014); analytically, an increase in channel steepness and palaeoslope can be attributed to a decrease in precipitation rate (to maintain similar total water discharge) (D'Arcy \& Whittaker, 2014). To reduce palaeoslopes by a factor of 2 , precipitation rate must typically be quadrupled (D’Arcy \& Whittaker, 2014). Despite the supposed warm and wet climate (Parker, 1976b; Kauffman \& Caldwell, 1993; Roberts \& Kirschbaum, 1995), few workers have argued for, or investigated, the possibility of increased aridity at the Blackhawk-Castlegate transition (van Wagoner, 1995; Adams \& Bhattacharya, 2005). In theory, increased palaeoslopes can be explained by decreased precipitation (D'Arcy \& Whittaker, 2014); however, here, no decrease in either flow velocities or unit discharges is reconstructed at the Blackhawk-Castlegate transition (Fig. 10). Generally, in down-dip locations, flow velocities and unit discharges are constant across this interval (Fig. 10D and F). At up-dip field sites, however, flow velocities are overall slightly greater during Castlegate Sandstone deposition relative to Blackhawk Formation deposition, but unit discharges remain similar for both.

With unit discharges constant in space and time, the crucial unknown is palaeochannel width. At minimum, channel widths can be considered as broadly the same across the Blackhawk-Castlegate transition. During Blackhawk Formation deposition, channelized sandbody widths of order 350 to $420 \mathrm{~m}$ offer a maximum limit on palaeochannel widths (Hampson et al., 2013; Flood \& Hampson, 2015). Meanwhile, during Castlegate Sandstone deposition, bar package widths are between $c a 60$ to $180 \mathrm{~m}$ (Chamberlin \& Hajek, 2019); assuming two or three threads, these bar widths might imply channel belt widths of order half a kilometre. However, planform stability estimates based on Parker (1976a) indicate that these rivers could have possessed anywhere between one and ten threads (Fig. 13), which could result in channel-belt widths up to and in excess of $1 \mathrm{~km}$. At maximum, this implies increased channel widths at the Blackhawk-Castlegate transition. Unless a significant decline in river widths is projected, then field results do not directly support a climatic driver. Consequently, the interpretation here is that increased channel steepness and palaeoslope at the Blackhawk-Castlegate transition is due to tectonically driven uplift in hinterland regions.

\section{Effectiveness of palaeohydrological and palaeomorphological reconstructions}

While quantitative reconstructions have led to significant advances in both the quantity and level of detailed information that can be extracted from fluvial strata (e.g. Ganti et al., 2019a), it is unclear how accurately these tools characterize ancient systems. Addressing this question is particularly important as sedimentology becomes increasingly numerical and it becomes easier to apply quantitative tools to stratigraphy (Duller et al., 2010; Whittaker et al., 2011; Holbrook \& Wanas, 2014; Ganti et al., 2019b). With extensive existing work on Late Cretaceous fluvial systems of central Utah, results in this study offer a unique opportunity to highlight consistencies and discrepancies between quantitative interpretations of fluvial palaeohydrology and more qualitative fieldbased facies and architectural interpretations.

To first order, whether point reconstructions of various morphological and hydrodynamic parameters agree with qualitative interpretations can be evaluated using independent proxies (derived from field measurements or facies interpretations). As previously mentioned, reconstructed flow depths agree with several secondary observations of bar heights (Adams \& Bhattacharya, 2005; Lynds \& Hajek, 2006; McLaurin \& Steel, 2007; Hajek \& Heller, 2012; Chamberlin \& Hajek, 2019) (Table S4 in Supplementary S6), which can be used as a direct proxy for flow depth (Bridge \& Tye, 2000; Hajek \& Heller, 2012). This agreement indicates that the uncertainty estimator in Eq. 2 is reasonable, and that cross-set heights can therefore be used to reconstruct reasonable flow-depth constraints and are useful as a bedform-scale approach. Such an approach is particularly useful in core data, locations with limited outcrop exposure, or deposits where the degree of bar preservation is poor. It is noted that scaling relations that relate cross-set heights with original bedform heights (and subsequently formative flow depths) are derived from theory and experiments that assume statistical steady state, in which flow is constant (Paola \& Borgman, 1991; Leclair, 2002; Jerolmack \& Mohrig, 2005). As such, agreement of flow depth reconstructions with bar heights might therefore imply that these dunes were formed in steady flow conditions (Ganti et al., 2020). This contrasts with literature that alludes to the preferential preservation of dunes in unsteady flow 
conditions (Reesink \& Bridge, 2007; Reesink \& Bridge, 2009; Reesink et al., 2015; Leary \& Ganti, 2020), and merits further work regarding the kinematic controls on dune preservation in this region.

For more complex palaeohydrological reconstructions, such as palaeoslopes and palaeorelief (Figs 7 to 9), it is not possible to directly corroborate estimates with independent proxies derived from field data. Nevertheless, it is still possible to evaluate reconstruction tools by contrasting commonly used methods. In this study the first approach used a theoretically-based Shields stress inversion (Eq. 3), whereas the second approach used the empirically-derived model (Eq. 4) of Trampush et al. (2014). Palaeoslope estimates derived from each approach are in broad agreement with one another. Each method typically recovers estimates of the same order of magnitude - in many cases the interquartile ranges of values overlap, and, in all cases, the full ranges of plausible values overlap (i.e. the whiskers in Figs 7 and 8). These point comparisons between the two methods are promising, and in line with comparisons made elsewhere (e.g. Ganti et al., 2019a). However, there are implications when larger spatial scales are concerned, imparting uncertainty that must be carried forward in interpretation of palaeorelief in the depositional reaches of these systems. Along the northern and southern transects, Shields stress inversion estimates consistently show higher differences in palaeoslope (i.e. higher slopes up-dip and lower slopes downdip) relative to palaeoslopes derived from the Trampush et al. (2014) method. This difference is likely an outcome of the Trampush et al. (2014) method using a continuous function to estimate slope, whereas the Shields stress inversion relies on a step-change empirical estimate for gravel or sand-bed rivers. Regardless of the method used, palaeoslope reconstructions are dependent on grain-size and flow-depth estimates. Because flow depths did not appreciably change in Blackhawk and Castlegate palaeorivers, variations in reconstructed slopes and derivative estimates (for example, water and sediment discharge) are largely driven by observed differences in grain size.

Despite the differences of the two methodologies on palaeorelief, estimates of palaeorelief can be compared with relief in modern systems possessing similar tectono-geographic set-ups. Palaeorelief estimates between $50 \mathrm{~m}$ and $100 \mathrm{~m}$ in depositional reaches of these ancient fluvial systems are reasonable when compared with relief in modern systems with a similar tectonogeographic setting. For example, one can return to the Andean analogue, but cross over to the eastern Andean cordillera and into the foreland basin and low-lying plains of the Amazon River. For most of its course, the Amazon long profile has a relief of less than $100 \mathrm{~m}$ (Milliman \& Farnsworth, 2013) - relief only exceeds $100 \mathrm{~m}$ in proximity to the range front (Milliman \& Farnsworth, 2013).

Finally, these results complement field evaluation of the nature of Blackhawk Formation and Castlegate Sandstone planforms, but also raise new questions. Channelized sandstone bodies of the Blackhawk Formation are typically 350 to $420 \mathrm{~m}$ wide (Adams \& Bhattacharya, 2005; Hampson et al., 2013; Flood \& Hampson, 2015), although a small proportion are much larger and some exceed $1 \mathrm{~km}$ (Flood \& Hampson, 2015). These sandstone bodies offer a maximum cap on palaeoflow width. The Blackhawk Formation is considered to mostly represent single-thread systems, which results in this study agree with. However there is significant field evidence that many channelized sandstone bodies of the Blackhawk Formation represent multi-thread systems with mid-channel bars, based on bar facies observations (Adams \& Bhattacharya, 2005; Hampson et al., 2013; Flood \& Hampson, 2015). Field observations of multi-thread Blackhawk fluvial systems of order hundreds of metres are inconsistent with the present results, which suggest that multithread systems would not have been stable (Fig. 13). Meanwhile, the Castlegate Sandstone is interpreted to be fully-braided from facies observations (Miall, 1993, 1994; Miall \& Arush, 2001; McLaurin \& Steel, 2007). Reported mean bar package widths of order 60 to $180 \mathrm{~m}$ for the Castlegate Sandstone (Chamberlin \& Hajek, 2019) would imply total channel widths $<1 \mathrm{~km}$ (assuming a few braids); this study's reconstructed planform stability estimates, which indicate that Castlegate systems should have been singlethreaded, are again inconsistent with sedimentological facies and architectural interpretations. Other quantitative reconstructions of planform have contradicted traditional field-based facies observations (Ganti et al., 2019a), and these inconsistencies must be treated carefully. The main limitation to reconstructing ancient channel planforms is a lack of reliable methods for estimating palaeochannel widths. Interpreting palaeochannel planforms from facies associations and stratigraphic-architectural data is not trivial, 
particularly where outcrop is limited or where observations are equivocal. However, in this case, a number of workers have concluded that braided conditions prevailed at the time of Castlegate Sandstone deposition (Lawton, 1986b; Miall, 1994; van Wagoner, 1995; Miall \& Arush, 2001) and occurred at times during Blackhawk Formation deposition (Adams \& Bhattacharya, 2005; Hampson et al., 2013; Flood \& Hampson, 2014, 2015). As such, it can be argued that further detailed work to test and reconcile facies-based and hydraulically derived interpretations of channel planforms is a pressing research goal.

\section{CONCLUSIONS}

Here a four-dimensional reconstruction of palaeohydrology in Late Cretaceous palaeorivers of central Utah, USA, is presented, using field data and a well-established quantitative framework. Overall, fluvial morphologies were similar in space and time, although marginally greater reconstructions of flow depths in southerly systems likely reflect the contribution of a longitudinal drainage component. The most prominent spatio-temporal change is an increase in palaeoslope at the Blackhawk-Castlegate transition by a factor of 1.5 to 4.0; this reflects an increase in palaeorelief (for the alluvial domain) from tens of metres during Blackhawk Formation deposition up to, and in excess of, $100 \mathrm{~m}$ during Castlegate Sandstone deposition, which persisted into Price River Formation times. The observation that unit water discharges do not change at the Blackhawk-Castlegate transition does not support a climatically driven increase in palaeoslope and channel steepness. Results therefore point to a tectonically driven palaeoslope increase. In deciphering the relative role of tectonic and climatic drivers, the main limitation in this study is uncertainty in palaeochannel widths, which directly affect total water discharges. Palaeochannel width reconstructions therefore remain a prominent research challenge.

Results complement and expand on extensive facies-based interpretations of these systems, which offers a unique opportunity to evaluate the efficacy of quantitative palaeohydrological reconstruction tools. Bedform-scale palaeoflow depth reconstructions are in good agreement with observations of preserved barforms. Moreover, while different palaeoslope reconstruction methods produce results that broadly agree, the results show that at larger spatial scales they over- predict and under-predict relief relative to one another, which has implications for quantifying alluvial palaeorelief and, therefore, the magnitude of change in relief at the Blackhawk-Castlegate transition. Finally, quantitative hydraulic reconstructions of planform somewhat disagree with facies-based interpretations. While this discrepancy ties back to uncertainty in palaeochannel widths, these results highlight that further work is required to reconcile hydraulically-based and facies-based approaches in order to facilitate their application in the geological past.

\section{ACKNOWLEDGEMENTS}

This research was primarily funded by the Natural Environment Research Council (NERC) Science and Solutions for a Changing Planet Doctoral Training Partnership (DTP), with additional funding by The Geological Society of London and The British Sedimentological Research Group. We thank Christopher Dean for support with planning fieldwork, George Hedley for support with field data collection, and Stephen Watkins for useful discussions. We would also like to thank Robert Mahon and Sandra Mann for their constructive reviews, which greatly enhanced this manuscript.

\section{DATA AVAILABILITY STATEMENT}

Field data are available in article Supporting Information.

\section{REFERENCES}

Adams, M.M. and Bhattacharya, J.P. (2005) No change in fluvial style across a sequence boundary, Cretaceous Blackhawk and Castlegate formations of central Utah, U.S.A. J. Sed. Res., 75(6), 1038-1051. https://doi.org/10. 2110/jsr.2005.080.

Allen, J.R.L. (1982a). Sedimentary Structures; Their Character and Physical Basis. Volume I (Vol. 30). Elsevier, Amsterdam, $592 \mathrm{pp}$.

Allen, J.R.L. (1982b). Sedimentary Structures; Their Character and Physical Basis. Volume II (Vol. 30). Elsevier, Amsterdam, 662 pp.

Allen, P.A. (2008a) From landscapes into geological history. Nature, 451, 274-276. https://doi.org/10.1038/nature06586.

Allen, P.A. (2008b) Time scales of tectonic landscapes and their sediment routing systems. Geol. Soc. Lond. Spec. Publ., 296(1), 7-28. https://doi.org/10.1144/sp296.2.

Allen, P.A., Armitage, J.J., Carter, A., Duller, R.A., Michael, N.A., Sinclair, H.D., Whitchurch, A.L. and Whittaker, 
A.C. (2013) The Qs problem: sediment volumetric balance of proximal foreland basin systems. Sedimentology, 60(1), 102-130. https://doi.org/10.1111/sed.12015.

Allmendinger, R.W. (1992) Fold and thrust tectonics of the western United States exclusive of the accreted terranes. In: The Cordilleran Orogen (Eds Burchfiel, B.C., Lipman, P.W. and Zoback, M.L.), pp. 583-607.Geological Society of America, Boulder, CO.

Andrews, E.D. (1984) Bed-material entrainment and hydraulic geometry of gravel-bed rivers in Colorado. Geol. Soc. Am. Bull., 95(3), 371-378. https://doi.org/10.1130/ 0016-7606(1984)95<371:BEAHGO>2.0.CO;2.

Armitage, J.J., Duller, R.A., Whittaker, A.C. and Allen, P.A. (2011) Transformation of tectonic and climatic signals from source to sedimentary archive. Nat. Geosci., 4(4), 231-235. https://doi.org/10.1038/ngeo1087.

Armstrong, R.L. (1968) Sevier Orogenic Belt in Nevada and Utah. Geol. Soc. Am. Bull., 79(4), 429-458. https://doi.org/ 10.1130/0016-7606(1968)79\%5B429:SOBINA\%5D2.0.CO;2.

Aschoff, J. and Steel, R. (2011a) Anatomy and development of a low-accommodation clastic wedge, upper Cretaceous, Cordilleran Foreland Basin, USA. Sed. Geol., 236(1), 1-24. https://doi.org/10.1016/j.sedgeo.2010.10.006.

Aschoff, J. and Steel, R. (2011b) Anomalous clastic wedge development during the Sevier-Laramide transition, North American Cordilleran foreland basin, USA. Geol. Soc. Am. Bull., 123(9-10), 1822-1835. https://doi.org/10.1130/ B30248.1.

Bartschi, N.C., Saylor, J.E., Lapen, T.J., Blum, M.D., Pettit, B.S. and Andrea, R.A. (2018) Tectonic controls on Late Cretaceous sediment provenance and stratigraphic architecture in the Book Cliffs, Utah. Geol. Soc. Am. Bull., 130(11-12), 1763-1781. https://doi.org/10.1130/ B31927.1.

Bhattacharya, J.P., Copeland, P., Lawton, T.F. and Holbrook, J. (2016) Estimation of source area, river paleodischarge, paleoslope, and sediment budgets of linked deep-time depositional systems and implications for hydrocarbon potential. Earth-Sci. Rev., 153, 77-110. https://doi.org/10.1016/j.earscirev.2015.10.013.

Bhattacharya, J. and Tye, B. (2004). Searching for modern Ferron analogs and application to subsurface interpretation. In: Regional to Wellbore Analog for FluvialDeltaic Reservoir Modeling: The Ferron Sandstone of Utah (Eds Chidsey Jr, T.C., Adams, R.D. and Morris, T.H.), AAPG Studies in Geology, 50, 39-57.

Bhattacharyya, P., Bhattacharya, J.P. and Khan, S.D. (2015) Paleo-channel reconstruction and grain size variability in fluvial deposits, Ferron Sandstone, Notom Delta, Hanksville, Utah. Sed. Geol., 325, 17-25. https://doi.org/ 10.1016/j.sedgeo.2015.05.001.

Boulton, S.J. and Whittaker, A.C. (2009) Quantifying the slip rates, spatial distribution and evolution of active normal faults from geomorphic analysis: field examples from an oblique-extensional graben, southern Turkey. Geomorphology, 104(3), 299-316. https://doi.org/10.1016/j. geomorph.2008.09.007.

Bradley, R.W. and Venditti, J.G. (2017) Reevaluating dune scaling relations. Earth-Sci. Rev., 165, 356-376. https:// doi.org/10.1016/j.earscirev.2016.11.004.

Brewer, C.J., Hampson, G.J., Whittaker, A.C., Roberts, G.G. and Watkins, S.E. (2020) Comparison of methods to estimate sediment flux in ancient sediment routing systems. Earth-Sci. Rev., 207, 103217. https://doi.org/10. 1016/j.earscirev.2020.103217.
Bridge, J.S. and Mackey, S.D. (1993). A revised alluvial stratigraphy model. In: Alluvial Sedimentation (Eds Marzo, M. and Puigdefábregas, C.), pp. 317-336.WileyBlackwell, Hoboken, NJ.

Bridge, J.S. and Tye, B. (2000) Interpreting the dimensions of ancient fluvial channel bars, channels, and channel belts from wireline-logs and cores. AAPG Bull., 84(8), 1205-1228. https://doi.org/10.1306/A9673C84-1738-11D78645000102C1865D.

Brooke, S.A.S., Whittaker, A., Armitage, J.J., D'Arcy, M. and Watkins, S.E. (2018) Quantifying sediment transport dynamics on alluvial fans from spatial and temporal changes in grain size, Death Valley, California. J. Geophys. Res. Earth Surf., 123, 2039-2067.

Bruhn, R.L., Picard, M.D. and Isby, J.S. (1986). Tectonics and Sedimentology of Uinta Arch, Western Uinta Mountains, and Uinta Basin. In: Paleotectonics and Sedimentation in the Rocky Mountain Region, United States (Ed. Peterson, J.A.), American Association of Petroleum Geologists, 41. 333-352.

Bryant, B. and Nichols, D.J. (1988) Late Mesozoic and early Tertiary reactivation of an ancient crustal boundary along the Uinta trend and its interaction with the Sevier orogenic belt. In: Interaction of the Rocky Mountain Foreland and the Cordilleran Thrust Belt (Eds Schmidt, C.J. and Perry W.J.), Geological Society of America Memoir, 171, 411-430.

Buhler, P.B., Fassett, C.I., Head, J.W. and Lamb, M.P. (2014) Timescales of fluvial activity and intermittency in Milna Crater, Mars. Icarus, 241, 130-147. https://doi.org/10.1016/ j.icarus.2014.06.028.

Carling, P.A. (1999) Subaqueous gravel dunes. J. Sed. Res., 69(3), 534-545. https://doi.org/10.2110/jsr.69.534.

Carlston, C.W. (1969) Longitudinal slope characteristics of rivers of the midcontinent and the Atlantic east gulf slopes. Int. Assoc. Sci. Hydrol. Bull., 14(4), 21-31. https:// doi.org/10.1080/02626666909493751.

Castelltort, S., Goren, L., Willett, S.D., Champagnac, J.-D., Herman, F. and Braun, J. (2012) River drainage patterns in the New Zealand Alps primarily controlled by plate tectonic strain. Nat. Geosci., 5(10), 744-748. https://doi. org/10.1038/ngeo1582.

Castelltort, S., Simpson, G. and Darrioulat, A. (2009) Slopecontrol on the aspect ratio of river basins. Terra Nova, 21 (4), 265-270. https://doi.org/10.1111/j.1365-3121.2009. 00880.x.

Castelltort, S. and Van Den Driessche, J. (2003) How plausible are high-frequency sediment supply-driven cycles in the stratigraphic record? Sed. Geol., 157(1), 3-13. https://doi.org/10.1016/S0037-0738(03)00066-6.

Chamberlin, E.P. and Hajek, E.A. (2019) Using bar preservation to constrain reworking in channel-dominated fluvial stratigraphy. Geology, 47(6), 531-534. https://doi. org/10.1130/G46046.1.

Champagnac, J.-D., Molnar, P., Sue, C. and Herman, F. (2012) Tectonics, climate, and mountain topography. J. Geophy. Res. Solid Earth, 117(B2), https://doi.org/10.1029/ 2011JB008348.

Chase, C.G., Gregory-Wodzicki, K.M., Parrish, J.T. and DeCelles, P.G. (1998) Topographic history of the Western Cordillera of North America and controls on climate. In: Tectonic Boundary Conditions for Climate Reconstructions (Crowley, T.J. and Burke, K.), Oxford Monographs on Geology and Geophysics, 39, 73-99.

Chen, C., Guerit, L., Foreman, B.Z., Hassenruck-Gudipati, H.J., Adatte, T., Honegger, L., Perret, M., Sluijs, A. and 
Castelltort, S. (2018) Estimating regional flood discharge during Palaeocene-Eocene global warming. Sci. Rep., 8(1), 13391. https://doi.org/10.1038/s41598-018-31076-3.

Chitale, S.V. (1970) River Channel Patterns. J. Hydraul. Div. Am. Soc. Civil Eng., 96, 201-221.

Church, M. and Rood, K. (1983) Catalogue of Alluvial River Channel Regime Data. University of British Columbia, Vancouver, $99 \mathrm{pp}$.

Cobban, W.A., McKinney, K.C., Obradovich, J.D. and Walasczyk, I. (2006) A USGS zonal table for the Upper Cretaceous Middle Cenomanian-Maastrichtian of the Western Interior of the United States based on Ammonites, Inoceramids, and radiometric ages: U.S. Geological Survey, Open-File Report 2006-1250, 1-46.

Colombera, L., Arévalo, O.J. and Mountney, N.P. (2017) Fluvial-system response to climate change: the PaleoceneEocene Tremp Group, Pyrenees, Spain. Global Planet. Change, 157, 1-17. https://doi.org/10.1016/j.gloplacha. 2017.08.011.

Constenius, K., Esser, R. and Layer, P. (2003) Extensional collapse of the Charleston-Nebo salient and its relationship to space-time variations in Cordilleran orogenic belt tectonism and continental stratigraphy. In: Cenozoic Systems of the Rocky Mountain Region (Eds Raynolds, R.G. and Flores, R.M.), Rocky Mountain Section, Society of Economic Paleontologists and Mineralogists, 303-353.

Dade, W.B. and Friend, P.F. (1998) Grain size, sediment transport regime, and channel slope in alluvial rivers. J. Geol., 106(6), 661-676. https://doi.org/10.1086/516052.

D'Arcy, M. and Whittaker, A.C. (2014) Geomorphic constraints on landscape sensitivity to climate in tectonically active areas. Geomorphology, 204, 366-381. https://doi.org/10.1016/j.geomorph.2013.08.019.

D'Arcy, M., Whittaker, A.C. and Roda-Boluda, D.C. (2017) Measuring alluvial fan sensitivity to past climate changes using a self-similarity approach to grain-size fining, Death Valley, California. Sedimentology, 64(2), 388-424. https:// doi.org/10.1111/sed.12308.

DeCelles, P.G. (1994) Late Cretaceous-Paleocene synorogenic sedimentation and kinematic history of the Sevier thrust belt, northeast Utah and southwest Wyoming. Geol. Soc. Am. Bull., 106, 32-56. https://doi.org/10.1130/0016-7606 (1994)106<0032:LCPSSA >2.3.CO;2.

DeCelles, P.G. (2004) Late Jurassic to Eocene evolution of the Cordilleran thrust belt and foreland basin system, western U.S.A. Am. J. Sci., 304, 105-168. https://doi.org/10.2475/ ajs.304.2.105.

DeCelles, P.G. and Coogan, J.C. (2006) Regional structure and kinematic history of the Sevier fold-and-thrust belt, central Utah. Geol. Soc. Am. Bull., 118(7/8), 841-864. https://doi.org/10.1130/B25759.1.

DiBiase, R.A., Whipple, K.X., Heimsath, A.M. and Ouimet, W.B. (2010) Landscape form and millennial erosion rates in the San Gabriel Mountains, CA. Earth Planet. Sci. Lett., 289(1), 134-144. https://doi.org/10.1016/j.epsl.2009.10. 036.

DiBiase, R.A. and Whipple, K.X. (2011) The influence of erosion thresholds and runoff variability on the relationships among topography, climate, and erosion rate. J. Geophys. Res., series F, 116(F4), https://doi.org/10.1029/ 2011JF002095.

Duller, R.A., Armitage, J.J., Manners, H.R., Grimes, S. and Jones, T.D. (2019) Delayed sedimentary response to abrupt climate change at the Paleocene-Eocene boundary, northern Spain. Geology, 47(2), 159-162. https://doi.org/ 10.1130/G45631.1.

Duller, R.A., Whittaker, A.C., Fedele, J.J., Whitchurch, A.L., Springett, J., Smithells, R., Fordyce, S. and Allen, P.A. (2010) From grain size to tectonics. J. Geophys. Res., series $F$, 115(F3), F03022. https://doi.org/10.1029/2009JF001495.

Eide, C.H., Müller, R. and Helland-Hansen, W. (2018) Using climate to relate water discharge and area in modern and ancient catchments. Sedimentology, 65(4), 1378-1389. https://doi.org/10.1111/sed.12426.

Ferguson, R.I. and Church, M. (2004) A simple universal equation for grain settling velocity. J. Sed. Res., 74(6), 933-937. https://doi.org/10.1306/051204740933.

Fernandes, V.M., Roberts, G.G., White, N. and Whittaker, A.C. (2019) Continental-scale landscape evolution: a history of north American topography. J. Geophys. Res., series F, 124(11), 2689-2722. https://doi.org/10.1029/ 2018JF004979.

Flint, J.J. (1974) Stream gradient as a function of order, magnitude, and discharge. Water Resour. Res., 10(5), 969-973. https://doi.org/10.1029/WR010i005p00969.

Flood, Y.S. and Hampson, G.J. (2014). Facies and architectural analysis to interpret avulsion style and variability: Upper Cretaceous Blackhawk Formation, Wasatch Plateau, central Utah, U.S.A. J. Sed. Res., 84(9), 743-762. https://doi.org/10.2110/jsr.2014.59.

Flood, Y.S. and Hampson, G.J. (2015) Quantitative analysis of the dimensions and distribution of channelized fluvial sandbodies within a large outcrop dataset: Upper Cretaceous Blackhawk Formation, Wasatch Plateau, central Utah, U.S.A. J. Sed. Res., 85(4), 315-336. https:// doi.org/10.2110/jsr.2015.25.

Foreman, B.Z. (2014) Climate-driven generation of a fluvial sheet sand body at the Paleocene-Eocene boundary in northwest Wyoming (USA). Basin Res., 26, 225-241. https://doi.org/10.1111/bre.12027.

Foreman, B.Z., Heller, P.L. and Clementz, M.T. (2012) Fluvial response to abrupt global warming at the Palaeocene/Eocene boundary. Nature, 491, 92-95. https:// doi.org/10.1038/nature11513.

Foreman, B.Z., Roberts, E.M., Tapanila, L., Ratigan, D. and Sullivan, P. (2015) Stable isotopic insights into paleoclimatic conditions and alluvial depositional processes in the Kaiparowits Formation (Campanian, south-central Utah, U.S.A.). Cretac. Res., 56, 180-192. https://doi.org/10.1016/j.cretres.2015.05.001.

Fouch, T.D., Lawton, T.F., Nichols, D.J., Cashion, W.B. and Cobban, W.A. (1983). Patterns and timing of synorogenic sedimentation in Upper Cretaceous rocks of central and northeast Utah. In: Mesozoic Paleogeography of WestCentral United States (Eds Reynolds, M.W. and Dolly, E.D.), SEPM Rocky Mountain Section, 305-336.

Fricke, H.C., Foreman, B.Z. and Sewall, J.O. (2010) Integrated climate model-oxygen isotope evidence for a North American monsoon during the Late Cretaceous. Earth Planet. Sci. Lett., 289(1-2), 11-21. https://doi.org/10. 1016/j.epsl.2009.10.018.

Ganti, V., Hajek, E.A., Leary, K., Straub, K.M. and Paola, C. (2020) Morphodynamic hierarchy and the fabric of the sedimentary record. Geophys. Res. Lett., 47(14), e2020GL087921. https://doi.org/10.1029/2020GL087921.

Ganti, V., Lamb, M.P. and McElroy, B. (2014) Quantitative bounds on morphodynamics and implications for reading the sedimentary record. Nat. Commun., 5(1), 3298. https:// doi.org/10.1038/ncomms4298. 
Ganti, V., Lamb, M.P. and Chadwick, A.J. (2019a) Autogenic erosional surfaces in fluvio-deltaic stratigraphy from floods, avulsions, and backwater hydrodynamics. J. Sed. Res., 89(8), 815-832. https://doi.org/10.2110/jsr.2019.40.

Ganti, V., Paola, C. and Foufoula-Georgiou, E. (2013) Kinematic controls on the geometry of the preserved cross sets. J. Geophys. Res., series F, 118(3), 1296-1307. https:// doi.org/10.1002/jgrf.20094.

Ganti, V., Whittaker, A., Lamb, M.P. and Fischer, W.W. (2019b) Low-gradient, single-threaded rivers prior to greening of the continents. Proc. Natl. Acad. Sci. USA, 116 (4), 11652-11657. https://doi.org/10.1073/pnas.1901642116.

Gill, M.A. (1971) Height of sand dunes in open channel flows. J. Hydr. Div., 97(12), 2067-2074.

Hack, J.T. (1957) Studies of longitudinal stream profiles in Virigina and Maryland. U.S. Geological Survey Professional Paper, 294-B, 45-97.

Hack, J.T. (1973) Stream profile analysis and stream gradient index. US Geological Survey Journal of Research, 1, 421-429.

Hajek, E.A., Heller, P.L. and Sheets, B.A. (2010) Significance of channel-belt clustering in alluvial basins. Geology, 38 (6), 535-538. https://doi.org/10.1130/G30783.1.

Hajek, E.A. and Heller, P.L. (2012) Flow-depth scaling in alluvial architecture and nonmarine sequence stratigraphy: example from the Castlegate Sandstone, central Utah, U.S.A. J. Sed. Res., 82(2), 121-130. https://doi.org/10. 2110/jsr.2012.8.

Hajek, E.A. and Wolinsky, M.A. (2012) Simplified process modeling of river avulsion and alluvial architecture: connecting models and field data. Sed. Geol., 257-260, 1-30. https://doi.org/10.1016/j.sedgeo.2011.09.005.

Hampson, G.J. (2010) Sediment dispersal and quantitative stratigraphic architecture across an ancient shelf. Sedimentology, 57(1), 96-141. https://doi.org/10.1111/j. 1365-3091.2009.01093.x.

Hampson, G.J., Duller, R.A., Petter, A.L., Robinson, R.A.J. and Allen, P.A. (2014) Mass-balance constraints on stratigraphic interpretation of linked alluvial-coastal-shelfal deposits from source to sink: example from Cretaceous Western Interior Basin, Utah and Colorado, U.S.A. J. Sed. Res., 84(11), 935-960. https://doi. org/10.2110/jsr.2014.78.

Hampson, G.J., Jewell, T.O., Irfan, N., Gani, M.R. and Bracken, B. (2013) Modest change in fluvial style with varying accommodation in regressive alluvial-to-coastalplain wedge: Upper Cretaceous Blackhawk Formation, Wasatch Plateau, central Utah, U.S.A. J. Sed. Res., 83(2), 145-169. https://doi.org/10.2110/jsr.2013.8.

Hampson, G.J., Royhan Gani, M., Sahoo, H., Rittersbacher, A., Irfan, N., Ranson, A., Jewell, T.O., Gani, N.D.S., Howell, J.A., Buckley, S.J. and Bracken, B. (2012) Controls on large-scale patterns of fluvial sandbody distribution in alluvial to coastal plain strata: Upper Cretaceous Blackhawk Formation, Wasatch Plateau, Central Utah, USA. Sedimentology, 59(7), 2226-2258. https://doi.org/10.1111/j.1365-3091.2012.01342.x.

Hay, W., Eicher, D.L. and Diner, R. (1993) Physical oceanography and water masses of the Cretaceous Western Interior Seaway. In: Evolution of the Western Interior Basin (Eds Caldwell, W.E.G. and Kauffman, E.G.), Geological Association of Canada, 297-318.

Hayden, A.T., Lamb, M.P., Fischer, W.W., Ewing, R.C., McElroy, B.J. and Williams, R.M.E. (2019) Formation of sinuous ridges by inversion of river-channel belts in Utah,
USA, with implications for Mars. Icarus, 332, 92-110. https://doi.org/10.1016/j.icarus.2019.04.019.

Hettinger, R.D. and Kirschbaum, M.A. (2002) Stratigraphy of the Upper Cretaceous Mancos Shale (upper part) and Mesaverde Group in the southern part of the Uinta and Piceance basins, Utah and Colorado. USGS Geologic Investigation Series: IMAP, 2764, 21. https://doi.org/10. 3133/i2764.

Holbrook, J. and Wanas, H. (2014) A fulcrum approach to assessing source-to-sink mass balance using channel paleohydrologic paramaters derivable from common fluvial data sets with an example from the Cretaceous of Egypt. J. Sed. Res., 84(5), 349-372. https://doi.org/10.2110/ jsr.2014.29.

Horton, B.K., Constenius, K.N. and DeCelles, P.G. (2004) Tectonic control on coarse-grained foreland-basin sequences: an example from the Cordilleran foreland basin, Utah. Geology, 32(7), 637-640. https://doi.org/10. 1130/G20407.1.

Hovius, N. (1996) Regular spacing of drainage outlets from linear mountain belts. Basin Res., 8(1), 29-44. https://doi. org/10.1111/j.1365-2117.1996.tb00113.x.

Jerolmack, D.J. and Mohrig, D. (2005) Frozen dynamics of migrating bedforms. Geology, 33(1), 57-60. https://doi.org/ 10.1130/G20897.1.

Jerolmack, D.J. and Paola, C. (2010) Shredding of environmental signals by sediment transport. Geophys. Res. Lett., 37(19), 1-5. https://doi.org/10.1029/2010gl044638.

Jerolmack, D.J. and Sadler, P. (2007) Transience and persistence in the depositional record of continental margins. J. Geophys. Res., series F, 112(F3), https://doi. org/10.1029/2006JF000555.

Jinnah, Z.A., Roberts, E.M., Deino, A.L., Larsen, J.S., Link, P.K. and Fanning, C.M. (2009) New ${ }^{40} \mathrm{Ar}^{-39} \mathrm{Ar}$ and detrital zircon U-Pb ages for the Upper Cretaceous Wahweap and Kaiparowits formations on the Kaiparowits Plateau, Utah: implications for regional correlation, provenance, and biostratigraphy. Cretac. Res., 30(2), 287-299. https://doi. org/10.1016/j.cretres.2008.07.012.

Kauffman, E.G. (1977) Geological and biological overview: Western Interior Basin. In: Cretaceous Facies, Faunas, and Paleoenvironments Across the Western Interior Basin. (Ed. Kauffman, E.G.), pp. 75-99.Rocky Mountain Association of Geologists, Denver, CO.

Kauffman, E.G. and Caldwell, W. (1993). The Western Interior Basin in space and time. In: Evolution of the Western Interior Basin (Eds Kauffman, E.G. and Caldwell, W.), Geological Association of Canada, Special Paper 39, 1-30.

Kirby, E. and Whipple, K. (2001) Quantifying differential rock-uplift rates via stream profile analysis. Geology, 29(5), 415-418. https://doi.org/10.1130/0091-7613(2001) 029<0415:QDRURV>2.0.CO;2.

Kirby, E., Whipple, K.X., Tang, W. and Chen, Z. (2003) Distribution of active rock uplift along the eastern margin of the Tibetan Plateau: inferences from bedrock channel longitudinal profiles. J. Geophy. Res. Solid Earth, 108(B4), https://doi.org/10.1029/2001JB000861.

Kirby, E. and Whipple, K.X. (2012) Expression of active tectonics in erosional landscapes. J. Struct. Geol., 44, 54-75. https://doi.org/10.1016/j.jsg.2012.07.009.

Lamb, M.P., Grotzinger, J.P., Southard, J.B. and Tosca, N.J. (2012) Were aqueous ripples on Mars formed by flowing brines? In: Sedimentary geology of Mars. (Eds Grotzinger, J.P. and Milliken, R.E.), SEPM Society for Sedimentary Geology, 102, 139-150. 
Lapôtre, M.G.A., Ielpi, A., Lamb, M.P., Williams, R.M.E. and Knoll, A.H. (2019) Model for the formation of singlethread rivers in barren landscapes and implications for pre-Silurian and Martian fluvial deposits. J. Geophys. Res., series $F$, 124(12), 2757-2777. https://doi.org/10.1029/ 2019JF005156.

Lawton, T.F. (1982) Lithofacies correlations within the Upper Cretaceous Indianola Group, central Utah. Utah Geol. Assoc. Publ., 10, 199-213.

Lawton, T.F. (1983) Late Cretaceous fluvial systems and the age of foreland uplifts in central Utah. In: Rocky Mountain Foreland Basins and Uplifts (Ed. Lowell, J.D.), pp. 181-199.Rocky Mountain Association of Geologists, Denver, CO.

Lawton, T.F. (1986a) Compositional trends within a clastic wedge adjacent to a fold-thrust belt: Indianola Group, central Utah, USA. In: Foreland Basins (Eds Allen, P.A. and Homewood, P.), pp. 411-423.Blackwell, London.

Lawton, T.F. (1986b) Fluvial Systems of the Upper Cretaceous Mesaverde Group and Paleocene North Horn Formation, Central Utah: A Record of Transition from Thin-Skinned to Thick-Skinned Deformation in the Foreland Region. In: Paleotectonics and sedimentation in the Rocky Mountain Region, United States (Ed. Peterson, J.A.), American Association of Petroleum Geologists, 41. https://doi.org/10.1306/M41456C20.

Lawton, T.F., Pollock, S.L. and Robinson, R.A.J. (2003) Integrating sandstone petrology and nonmarine sequence stratigraphy: application to the Late Cretaceous fluvial systems of southwestern Utah, USA. J. Sed. Res., 73, 398-406.

Leary, K.C.P. and Ganti, V. (2020) Preserved fluvial cross strata record bedform disequilibrium dynamics. Geophys. Res. Lett., 47(2), e2019GL085910. https://doi.org/10.1029/ 2019GL085910.

Leclair, S.F. (2002) Preservation of cross-strata due to the migration of subaqueous dunes: an experimental investigation. Sedimentology, 49(6), 1157-1180. https:// doi.org/10.1046/j.1365-3091.2002.00482.x.

Leclair, S.F. and Bridge, J.S. (2001) Quantitative interpretation of sedimentary structures formed by river dunes. J. Sed. Res., 71(5), 713-716. https://doi.org/10. 1306/2DC40962-0E47-11D7-8643000102C1865D.

Leopold, L.B. and Maddock Jr, T. (1953) The hydraulic geometry of stream channels and some physiographic implications. USGS Prof. Pap., 252, 64. https://doi.org/10. 3133/pp252.

Leopold, L.B. and Wolman, M.G. (1957) River channel patterns: braided, meandering, and straight. USGS Prof. Pap., 282B, 50. https://doi.org/10.3133/pp282B.

Li, Y., Bhattacharya, J.P., Ahmed, S. and Garza, D. (2018) Re-evaluating the paleogeography of the river-dominated and wave-influenced Ferron Notom Delta, Southern Central Utah: an integration of detailed facies-architecture and paleocurrent analysis. J. Sed. Res., 88(2), 214-240. https://doi.org/10.2110/jsr.2018.9.

Lin, W. and Bhattacharya, J.P. (2017) Estimation of sourceto-sink mass balance by a fulcrum approach using channel paleohydrologic parameters of the Cretaceous Dunvegan Formation, Canada. J. Sed. Res., 87(1), 97-116. https://doi. org/10.2110/jsr.2017.1.

Lynds, R. and Hajek, E. (2006) Conceptual model for predicting mudstone dimensions in sandy braided-river reservoirs. AAPG Bull., 90(8), 1273-1288. https://doi.org/ 10.1306/03080605051.
Lyster, S.J., Whittaker, A.C., Allison, P.A., Lunt, D.J. and Farnsworth, A. (2020) Predicting sediment discharges and erosion rates in deep time-examples from the late Cretaceous North American continent. Basin Res., 32(6), 1547-1573. https://doi.org/10.1111/bre.12442.

Mahon, R.C. and McElroy, B. (2018) Indirect estimation of bedload flux from modern sand-bed rivers and ancient fluvial strata. Geology, 46(7), 579-582. https://doi.org/10. 1130/G40161.1.

McLaurin, B.T. and Steel, R.J. (2007) Architecture and origin of an amalgamated fluvial sheet sand, lower Castlegate Formation, Book Cliffs, Utah. Sed. Geol., 197(3), 291-311. https://doi.org/10.1016/j.sedgeo.2006.10.005.

Miall, A.D. (1993) The architecture of fluvial-deltaic sequences in the Upper Mesaverde Group (Upper Cretaceous), Book Cliffs, Utah. Geol. Soc. Lond. Spec. Publ., 75(1), 305-332. https://doi.org/10.1144/GSL.SP.1993.075.01.19.

Miall, A.D. (1994) Reconstructing fluvial macroform architecture from two-dimensional outcrops; examples from the Castlegate Sandstone, Book Cliffs, Utah. J. Sed. Res., 64(2b), 146-158. https://doi.org/10.1306/D4267F782B26-11D7-8648000102C1865D.

Miall, A.D. and Arush, M. (2001) The Castlegate Sandstone of the Book Cliffs, Utah: sequence stratigraphy, paleogeography, and tectonic controls. J. Sed. Res., 71(4), 537-548. https://doi.org/10.1306/103000710537.

Miller, I.M., Johnson, K., Kline, D.E., Nichols, D.J. and Barclay, R. (2013) A Late Campanian Flora from the Kaiparowits Formation, southern Utah, and a brief overview of the widely sampled but little-known Campanian vegetation of the Western Interior of North America. At the Top of the Grand Staircase: The Late Cretaceous of southern Utah, 107-131.

Milliman, J.D. and Farnsworth, K.L. (2013) River Discharge to the Coastal Ocean: A Global Synthesis, pp. 1-384. Cambridge University Press, Cambridge.

Paola, C. and Borgman, L. (1991) Reconstructing random topography from preserved stratification. Sedimentology, 38(4), 553-565. https://doi.org/10.1111/j.1365-3091.1991.tb 01008.x.

Parker, G. (1976) On the cause and characteristic scales of meandering and braiding in rivers. J. Fluid. Mech., 76(3), 457-480. https://doi.org/10.1017/S0022112076000748.

Parker, G. (2004). 1D Sediment Transport Morphodynamics with Applications to Rivers and Turbidity Currents. EBook, University of Illinois. Available at: http://hydrolab. illinois.edu/people/parkerg/default.asp

Parker, L.R. (1976) The paleoecology of the fluvial coal-forming swamps and associated floodplain environments in the Blackhawk Formation (Upper Cretaceous) of central Utah. Brigham Young University, Geological Studies, 22, 99-116.

Paul, J.D., Roberts, G.G. and White, N. (2014) The African landscape through space and time. Tectonics, 33(6), 898-935. https://doi.org/10.1002/2013TC003479.

Pederson, J.L. and Tressler, C. (2012) Colorado River longprofile metrics, knickzones and their meaning. Earth Planet. Sci. Lett., 345-348, 171-179. https://doi.org/10. 1016/j.epsl.2012.06.047.

Perry, G.D., Duffy, P.B. and Miller, N.L. (1996) An extended data set of river discharges for validation of general circulation models. J. Geophys. Res. Atmos., 101(D16), 21339-21349. https://doi.org/10.1029/96JD00932.

Pettit, B.S., Blum, M., Pecha, M., McLean, N., Bartschi, N.C. and Saylor, J.E. (2019). Detrital-zircon U-Pb paleodrainage reconstruction and geochronology of the Campanian 
Blackhawk-Castlegate succession, Wasatch Plateau and Book Cliffs, Utah, U.S.A. J. Sed. Res., 89(4), 273-292. https://doi.org/10.2110/jsr.2019.18.

Reesink, A.J.H. and Bridge, J.S. (2007) Influence of superimposed bedforms and flow unsteadiness on formation of cross strata in dunes and unit bars. Sed. Geol., 202(1), 281-296. https://doi.org/10.1016/j.sedgeo. 2007.02.005.

Reesink, A.J.H. and Bridge, J.S. (2009) Influence of bedform superimposition and flow unsteadiness on the formation of cross strata in dunes and unit bars - Part 2, further experiments. Sed. Geol., 222(3), 274-300. https://doi.org/ 10.1016/j.sedgeo.2009.09.014.

Reesink, A.J.H., Van den Berg, J.H., Parsons, D.R., Amsler, M.L., Best, J.L., Hardy, R.J., Orfeo, O. and Szupiany, R.N. (2015) Extremes in dune preservation: controls on the completeness of fluvial deposits. Earth Sci. Rev., 150, 652-665. https://doi.org/10.1016/j.earscirev.2015.09.008.

van Rijn, L.C. (1984a) Sediment transport III: bedforms and alluvial roughness. J. Hydraul. Eng., 110(12), 1733-1754. https://doi.org/10.1061/(ASCE)0733-9429(1984)110:12 (1733).

van Rijn, L.C. (1984b) Sediment transport, part II: suspended load transport. J. Hydraul. Eng., 110(11), 1613-1641. https://doi.org/10.1061/(ASCE)0733-9429(1984)110:11 (1613).

Rittersbacher, A., Howell, J.A. and Buckley, S.J. (2014). Analysis of fluvial architecture in the Blackhawk Formation, Wasatch Plateau, Utah, U.S.A., using large 3D photorealistic models. J. Sed. Res., 84(2), 72-87. https:// doi.org/10.2110/jsr.2014.12.

Roberts, E.M. (2007) Facies architecture and depositional environments of the Upper Cretaceous Kaiparowits Formation, southern Utah. Sed. Geol., 197(3), 207-233. https://doi.org/10.1016/j.sedgeo.2006.10.001.

Roberts, E.M., Tapanila, L. and Mijal, B. (2008) Taphonomy and sedimentology of storm-generated continental shell beds: a case example from the Cretaceous Western Interior Basin. J. Geol., 116(5), 462-479. https://doi.org/10.1086/ 590134.

Roberts, G.G., White, N.J., Martin-Brandis, G.L. and Crosby, A.G. (2012) An uplift history of the Colorado Plateau and its surroundings from inverse modeling of longitudinal river profiles. Tectonics, 31(4), https://doi.org/10.1029/ 2012 TC003107.

Roberts, G.G., White, N. and Lodhia, B.H. (2019) The generation and scaling of longitudinal river profiles. $J$. Geophys. Res. series F, 124(1), 137-153. https://doi.org/10. 1029/2018JF004796.

Roberts, L.N.R. and Kirschbaum, M.A. (1995) Paleogeography and the Late Cretaceous of the Western Interior of middle North America: coal distribution and sediment accumulation. USGS Prof. Pap., 1561, 1-65. https://doi.org/10.3133/pp1561.

Robinson, R.A.J. and Slingerland, R.L. (1998) Grain-size trends, basin subsidence and sediment supply in the Campanian Castlegate Sandstone and equivalent conglomerates of Central Utah. Basin Res., 10, 109-127.

Romans, B.W., Castelltort, S., Covault, J.A., Fildani, A. and Walsh, J.P. (2016) Environmental signal propagation in sedimentary systems across timescales. Earth-Sci. Rev., 153, 7-29. https://doi.org/10.1016/j.earscirev.2015.07.012.

Rudge, J.F., Roberts, G.G., White, N.J. and Richardson, C.N. (2015) Uplift histories of Africa and Australia from linear inverse modeling of drainage inventories. J. Geophys. Res., series $F, \quad \mathbf{1 2 0}(5), \quad 894-914 . \quad$ https://doi.org/10.1002/ 2014JF003297.

Sadler, P.M. (1981) Sediment accumulation rates and the completeness of stratigraphic sections. J. Geol., 89, 569-584. https://doi.org/10.1086/628623.

Schulze, K., Hunger, M. and Döll, P. (2005) Simulating river flow velocity on global scale. Adv. Geosci., 5, 133-136.

Schumm, S.A. (1968) River adjustment to altered hydrologic regimen - Murrumbidgee River and paleochannels, Australia. USGS Prof. Pap., 598, 65. https://doi.org/10.3133/pp598.

Sewall, J.O. and Fricke, H.C. (2013) Andean-scale highlands in the Late Cretaceous Cordillera of the North American western margin. Earth Planet. Sci. Lett., 362, 88-98. https://doi.org/10.1016/j.epsl.2012.12.002

Sharma, S., Bhattacharya, J.P. and Richards, B. (2017) Source-to-sink sediment budget analysis of the Cretaceous Ferron Sandstone, Utah, U.S.A., using the fulcrum approach. J. Sed. Res., 87(6), 594-608. https://doi.org/10. 2110/jsr.2017.23.

Soria-Jáuregui, Á., Jiménez-Cantizano, F. and Antón, L. (2019) Geomorphic and tectonic implications of the endorheic to exorheic transition of the Ebro River system in northeast Iberia. Quatern. Res., 91(2), 472-492. https:// doi.org/10.1017/qua.2018.87.

Spieker, E.M. (1946). Late Mesozoic and early Cenozoic history of central Utah. USGS Prof. Pap., 205D. https:// doi.org/10.3133/pp205D.

Straub, K.M., Duller, R.A., Foreman, B.Z. and Hajek, E.A. (2020) Buffered, incomplete, and shredded: the challenges of reading an imperfect stratigraphic record. J. Geophys. Res. series F, 125(3), e2019JF005079. https://doi.org/10. 1029/2019JF005079.

Stucky de Quay, G., Kite, E.S. and Mayer, D.P. (2019) Prolonged fluvial activity from channel-fan systems on Mars. J. Geophys. Res. Planet., 124(11), 3119-3139. https:// doi.org/10.1029/2019JE006167.

Szwarc, T.S., Johnson, C.L., Stright, L.E. and McFarlane, C.M. (2015) Interactions between axial and transverse drainage systems in the Late Cretaceous Cordilleran foreland basin: evidence from detrital zircons in the Straight Cliffs Formation, southern Utah, USA. Geol. Soc. Am. Bull., 127 (3-4), 372-392. https://doi.org/10.1130/B31039.1.

Trampush, S.M., Huzurbazar, S. and McElroy, B. (2014) Empirical assessment of theory for bankfull characteristics of alluvial channels. Water Resour. Res., 50(12), 9211-9220. https://doi.org/10.1002/2014WR015597.

Trower, E.J., Ganti, V., Fischer, W.W. and Lamb, M.P. (2018) Erosional surfaces in the Upper Cretaceous Castlegate Sandstone (Utah, USA): sequence boundaries or autogenic scour from backwater hydrodynamics? Geology, 46(8), 707-710. https://doi.org/10.1130/G40273.1.

Tucker, G.E. and Whipple, K.X. (2002) Topographic outcomes predicted by stream erosion models: sensitivity analysis and intermodel comparison. J. Geophys. Res. Solid Earth, 107(B9), ETG 1-1-ETG 1-16. https://doi.org/ 10.1029/2001JB000162.

van Wagoner, J.C. (1995). Sequence stratigraphy and marine to nonmarine facies architecture of Foreland Basin Strata, Book Cliffs, Utah, U.S.A. In: Sequence Stratigraphy of Foreland Basin Deposits: Outcrop and Subsurface Examples from the Cretaceous of North America (Eds van Wagoner, J.C. and Bertram, G.T.), 64, pp. 137-223. American Association of Petroleum Geologists, Tulsa, OK.

Watkins, S.E., Whittaker, A.C., Bell, R.E., McNeill, L.C., Gawthorpe, R.L., Brooke, S.A.S. and Nixon, C.W. (2018) 
Are landscapes buffered to high-frequency climate change? A comparison of sediment fluxes and depositional volumes in the Corinth Rift, central Greece, over the past 130 k.y. Geol. Soc. Am. Bull., 131, 372-388. https://doi. org/10.1130/B31953.1.

Whipple, K.X. (2004) Bedrock rivers and the geomorphology record of active orogens. Annu. Rev. Earth Planet. Sci., 32 (1), 151-185. https://doi.org/10.1146/annurev.earth.32. 101802.120356 .

Whitchurch, A., Carter, A., Sinclair, H., Duller, R., Whittaker, A. and Allen, P. (2011) Sediment routing system evolution within a diachronously uplifting orogen: insights from detrital zircon thermochronological analyses from the South-Central Pyrenees. Am. J. Sci., 311, 442-482. https://doi.org/10.2475/05.2011.03.

Whittaker, A.C. (2012) How do landscapes record tectonics and climate? Lithosphere, 4(2), 160-164. https://doi.org/10. 1130/rf.1003.1.

Whittaker, A.C., Duller, R.A., Springett, J., Smithells, R.A., Whitchurch, A.L. and Allen, P.A. (2011) Decoding downstream trends in stratigraphic grain size as a function of tectonic subsidence and sediment supply. Geol. Soc. Am. Bull., 123(7-8), 1363-1382. https://doi.org/10.1130/ B30351.1.

Wobus, C.W., Tucker, G.E. and Anderson, R.S. (2010) Does climate change create distinctive patterns of landscape incision? J. Geophys. Res. series F, 115(F4), https://doi. org/10.1029/2009JF001562.

Wobus, C., Whipple, K.X., Kirby, E., Snyder, N., Johnson, J., Spyropolou, K., Cyosby, B. and Sheehan, D. (2006) Tectonics from topography: procedures, promise, and pitfalls. In: Tectonics, climate, and landscape evolution (Eds Willett, S.D., Hovius, N., Brandon, M.T. and Fisher, D.M.), pp. 55-74.Geological Society of America.

Wolfe, J.A. and Upchurch Jr, G.R. (1987) North American nonmarine climates and vegetation during the Late Cretaceous. Palaeogeogr Palaeoclimatol Palaeoecol, 61 (Supplement C), 33-77. https://doi.org/10.1016/0031-0182 (87)90040-X.

Wolman, M.G. (1954) A method of sampling coarse river-bed material. Trans. Am. Geophys. Union, 35(6), 951-956. https://doi.org/10.1029/TR035i006p00951.

Wright, S. and Parker, G. (2004) Flow resistance and suspended load in sand-bed rivers: simplified stratification model. J. Hydraul. Eng., 130(8), 796-805. https://doi.org/ 10.1061/(ASCE)0733-9429(2004)130:8(796).

Yalin, M.S. (1964) Geometrical properties of sand waves. $J$. Hydraul. Div., 90(5), 105-119.

Yoshida, S., Willis, A. and Miall, A.D. (1996) Tectonic control of nested sequence architecture in the Castlegate Sandstone (Upper Cretaceous), Book Cliffs, Utah. J. Sed. Res., 66(4), 737-748.

Zhang, J., Covault, J., Pyrcz, M., Sharman, G., Carvajal, C. and Milliken, K. (2018) Quantifying sediment supply to continental margins: application to the Paleogene Wilcox Group, Gulf of Mexico. AAPG Bull., 102(9), 1685-1702. https://doi.org/10.1306/01081817308.

Zhisheng, A., Kutzbach, J.E., Prell, W.L. and Porter, S.C. (2001) Evolution of Asian monsoons and phased uplift of the Himalaya-Tibetan plateau since Late Miocene times. Nature, 411(6833), 62-66. https://doi.org/10.1038/35075035.
Manuscript received 15 October 2020; revision accepted 25 March 2021

\section{Supporting Information}

Additional information may be found in the online version of this article:

Supplementary S1. Variables list. Supplementary S2. Field localities.

Fig S1. Study area showing key localities mentioned in the supplement, reproduced from Fig. 1 in the main manuscript.

Table S1. Field localities visited in this study, for each field area (e.g. Price Canyon, Wattis Road, etc).

Supplementary S3. Regional correlation - further information.

Fig S2. Measured section through the Sixmile Canyon Formation (Indianola Group) and (extrapolated) Price River Conglomerate at Mellor Canyon.

Supplementary S4. Field data.

Table S2. Grain-size data collected and used in this study.

Table. S3. Cross-set data collected and used in this study.

Supplementary S5. Grain size sample sufficiency.

Fig S3. The iterative convergence of median grainsize for (A) pebbles-cobbles, (B) medium-coarse pebbles, (C) granules-fine pebbles, (D) medium-coarse sand, and (E) fine-medium sand, as calculated from scaled photographs in ImageJ software.

Fig S4. The iterative convergence of median grainsize for different outcrops of gravel-grade sediments, as calculated from field Wolman counts.

Supplementary S6. Secondary field data.

Table S4. A compilation of field measurements (secondary data from published literature) for architectural scale elements, e.g. bar heights, that are commonly used as palaeoflow depth proxies.

Table S5. A compilation of field measurements (secondary data from published literature) for architectural scale elements, e.g. sandstone bodies, that are commonly used as a proxy to infer the magnitude of channel width.

Supplementary S7. Goodness of fits on palaeoslope profiles including resolved steepness indexes.

Table S6. Steepness indexes, $\mathrm{k}_{\mathrm{s}}$, recovered for the defined northern and southern depositional-dip transects, through each stratigraphic interval (1-7), where possible.

Supplementary S8. Additional results.

Fig S5. Reconstructed palaeoflow depths for the five parallel fluvial systems, for each stratigraphic interval where possible. 